\title{
SLIDING INTO POVERTY? CROSS-NATIONAL PATTERNS OF INCOME SOURCE CHANGE AND INCOME DECAY IN OLD AGE
}

\author{
James M. Williamson* and Timothy M. Smeeding \\ CRR WP 2004-25 \\ Released: November 2004 \\ Draft Submitted: October 2004 \\ Center for Retirement Research at Boston College \\ 550 Fulton Hall \\ 140 Commonwealth Ave. \\ Chestnut Hill, MA 02467 \\ Tel: 617-552-1762 Fax: 617-552-1750 \\ http://www.bc.edu/crr
}

* James M. Williamson works for the U.S. Environmental Protection Agency. Timothy M.

Smeeding is the Maxwell Professor of Public Policy and the Project Director of the Luxembourg Income Study. The research reported herein was supported by the Center for Retirement Research at Boston College pursuant to a grant from the U.S. Social Security Administration(SSA). The opinions and conclusions are solely those of the authors and should not be construed as representing the opinions or policy of the SSA or any agency of the Federal Government or the Center for Retirement Research at Boston College. Contact Author Address: US EPA, 26 W. Martin Luther King Dr. Cincinnati, OH 45268. Phone: 513-569-7501. Email: williamson.james@epa.gov.

(C) 2004, by James M. Williamson and Timothy M. Smeeding. All rights reserved. Short sections of text, not to exceed two paragraphs, may be quoted without explicit permission provided that full credit, including (C) notice, is given to the source. 


\title{
About the Center for Retirement Research
}

The Center for Retirement Research at Boston College, part of a consortium that includes a parallel centers at the University of Michigan and the National Bureau of Economic Research, was established in 1998 through a grant from the Social Security Administration. The goals of the Center are to promote research on retirement issues, to transmit new findings to the policy community and the public, to he lp train new scholars, and to broaden access to valuable data sources. Through these initiatives, the Center hopes to forge a strong link between the academic and policy communities around an issue of critical importance to the nation's future.

\author{
Center for Retirement Research at Boston College \\ 550 Fulton Hall \\ 140 Commonwealth Ave. \\ Chestnut Hill, MA 02467 \\ phone: 617-552-1762 fax: 617-552-1750 \\ e-mail: crr@bc.edu \\ http://www.bc.edu/crr
}

\section{Affiliated Institutions:}

American Enterprise Institute

Center for Strategic and International Studies

The Brookings Institution

Massachusetts Institute of Technology

Max Planck Institute for Demographic Research

Syracuse University

Urban Institute 


\begin{abstract}
This article examines the change in the mix of income and benefits that older adults receive as they age, with a focus on older women. The study is a cross-national comparison of five OECD countries using the Luxemburg Income Study database. We investigate the change of private income and social benefits following synthetic cohorts for two decades. These results reveal that older women rely heavily on socially provided benefits for a majority of their income, and these benefits are primarily responsible for whether older women find themselves in poverty or not. Older men and women in countries with relatively generous (or well targeted) social retirement and social transfer benefits have lower levels of poverty. Housing appears to be a particularly important factor. Older homeowners are less likely to be in poverty than renters. As the value of homes and homeownership increase, housing will become an especially important source of support in old age.
\end{abstract}

Keywords: income ; retirement; old age; poverty; cross national 


\section{Introduction}

The cost of aging societies is a major policy issue in most rich countries. The combined public sector costs of income support and health care in an age of declining fertility will force most rich nations to make drastic changes in their social retirement and social safety nets over the coming 25 years (Jackson and Howe 2003; Yamada and Casey 2002; OECD 1998). While some welfare states are more at risk than others, those that spend relatively larger amounts of their public resources on older persons compared to the young (such as the United States and north central Europe) may face the most difficult transition to financial stability (Lynch 2001). Already, German old-age social security retirement benefits are being trimmed for recent retirees (Immervoll 2004). As changes in these systems are made, they will affect not only retirement policies and economic well-being at the age of retirement, but also the eventual adequacy of retirement incomes in old age. Our paper is about the way that "retirement" income packages change as persons age. In particular, we are interested in the ways in which retirement income sources change and the adequacy of those incomes at older ages. In order to investigate this question, we use the rich detail of incomes for cohorts of the aged in five nations afforded by the Luxembourg Income Study project to investigate the changes in the level and composition of the incomes of those born early last century, the majority of whom are now very old.

Previous research has shown that the oldest old, especially older widows, divorcees and especially single women living alone, have the highest chance of poverty in all nations (Smeeding and Sandstrom forthcoming; Smeeding and Williamson 2001). As cohorts age, the pattern of lower incomes (relative to younger cohorts) and higher poverty is extant in most rich nations (Osberg 2001; Yamada 2002; Smeeding and 
Sullivan 1998). We also know from United States and German panel data studies that widowhood is a major cause of elder women poverty (Burkhauser et al. 2003; Yamada and Casey 2002). But we also know that, by design, some national old-age benefit systems are able to better maintain the relative incomes of the aged in general and older women in particular as cohorts and the people in them age. How and why these changes in incomes at older ages take place is, however, not well known or understood.

We are all aware that earned incomes decline with reduced labor force participation in old-age. Less is known, however, about the rate at which other sources of incomes decline in old-age, and the role of assets (e.g., homes) and income from savings in protecting the aged against such declines. Nations have different rules for adjusting public old age benefits for price or wage changes, and many nations have floors for income protection which are indexed differently than other types of old-age benefits. In some nations, benefit levels change when demographic events occur (death of a spouse, changes in household composition for survivors, divorce) or in compensation for earlier demographic events (e.g. for time spent not at paid work, but in raising children). Occupational pensions behave still differently than do social retirement schemes, where the choice of survivor options, indexing beyond retirement age and other features differ within as well as between nations. A better understanding of how these complicated changes in income packages take place over time and across nations is the main goal of this paper.

To the extent that we are able to uncover the elements of both incomes and assets which protect older persons, we are in a position to recommend polices which will help protect well-being as populations age and as the income mix also changes with aging populations. Indeed, as we shall see, some nations have already made policy changes 
which are aimed at preventing steep declines in incomes at older ages as a part of their social policy mix. On the other hand, other nations have needed to reduce benefits to current retirees (Germany) or examine indexation and relative levels of "first tier" benefits (United Kingdom; see Feldstein 2004; Immervoll 2004; and Yamada and Casey 2001). Others like the United States will continue to experience higher future poverty rates for vulnerable groups unless compensating changes are made (Butrica, Smith, and Toder 2002; Smeeding 1999). But changes in "Social Retirement" polices aimed at financial stability and retirement practices alone are often not well tuned to the economic needs of the truly old, particularly in times of changing family situations and rapid increases in lifespans at older ages (Steuerle, Favreault and Sammartino 2002; Smeeding 1999). The plan of the paper is as follows: In the next section we discuss the data for the five countries used in our study and present the methods by which we document the decay of benefits and slide into poverty. In Section III we present the results of our cohort analysis starting with the five key measures of income in later life. We follow in Section III.6 with an analysis of poverty, and present the differences between older adults who own a home and older adults who rent a home in Section III.7. Finally, Section IV wraps up the paper with our conclusions on the change in poverty and income across five nations.

\section{Data and methods}

In this section we outline the data and methods we use to document the change in income and poverty across five OECD nations. Our analysis focuses on those who will spend the most time in old age, and is therefore concerned with the evolution over time of the mix of income and benefits that older women receive. Below, we describe the 
methods necessary to create birth cohorts of older women, after first discussing the crosssectional multinational data we use.

\section{II.1. Data}

To facilitate our comparative study we use data from the Luxembourg Income Study (LIS). LIS is a rich source of multinational demographic, income and expenditure data from 28 countries. The data collection is a cross-sectional time series that spans more than 25 years and contains observations on the person level, household, and child level. The data originate from each country's household income survey. For example, the United States data are provided to LIS by the Current Population Survey and the Canadian data are provided by Statistics Canada. The years we select begin in the early 1970s and include the waves of the most recent data available from LIS. In our analysis we use data from the five countries for which we have the longest time series of comparable data: Australia, Canada, Sweden, United Kingdom, and the United States.

The advantage of using LIS data for our research is twofold. First, the LIS data are multinational and the data for its member countries have been pre-assembled in one location. Second, member country micro-data have been harmonized by LIS. Harmonization is important because the retirement benefits package in one country looks very different from the retirement benefits package in another country. When we compare the level of "social retirement benefits" across nations, we want the variables to be as similar as possible. The value of the LIS data set is the computation of standard harmonized variables across countries. ${ }^{1}$

Our study is concerned with the overall decline in income and wealth measures, especially for older women. We document the general decline first by measuring the decline in net disposable income. The net disposable income variable in the LIS data is 
composed of income variables that range from wages and salary to means-tested cash benefits and unemployment benefits, net of taxes and mandatory employee contributions. We also map the change in the composition of income and benefits from private and state-provided sources. The private sources of income include 1) property cash income (e.g., any interest, rents or dividends); and 2) occupational pensions and labor-earnings. The benefits provided by state sources are 1) social retirement benefits, which are defined as cash social security payments for old age or survivors; and 2) income maintenance benefits which are income and/or asset which include social insurance payments, income maintenance benefits, certain allowances such as for a child or family, and near-cash benefits, such as food stamps and housing allowances.

An important aspect of the decay in benefits is the corresponding rise in poverty. We consider a person (man or woman) to be in poverty if their net DPI is less than or equal to 50 percent of the median income for the population as a whole. We account for the economies of scale of sharing a household dwelling with others by adjusting disposable personal income by an equivalence scale. The scale we use is the square root of the number of household members as suggested by Atkinson, Rainwater, and Smeeding (1995). ${ }^{2}$ We also specify the poverty figure at 40 percent of the median disposable personal income as a simple way of testing the dispersion of impoverishment throughout the income distribution. By comparing poverty rates at several thresholds, we are better able to detail how poverty is changing in each country over time. Moreover, we are able to highlight a vulnerable group of poor women for whom specific targeted policies can help.

Finally, to address the issue of assets we consider both flows of property income (from own savings and pension savings) and differences according to homeownership. 
We are not yet able to assess the actual net worth of the aged. The new Luxembourg Wealth Study (LWS) data will allow us to do so on a comparative cross-national basis. ${ }^{3}$

\section{II.2. Methods}

To document the decay of benefits across time we construct three synthetic birth cohorts. The cohorts are synthetic in the sense that each year of data is a cross-sectional sample of the respective country, and from year to year the cross-section takes a sample of different people and assigns them to a cohort. We therefore do not follow the same individual people over time, but a sample of persons born between the specified years. ${ }^{4}$

To construct each cohort, we use ten- year time intervals. Our first cohort consists of women who were born between 1900 and 1909, and the second and third birth cohorts follow accordingly. LIS provides many waves of data for each of these nations and we select between four and six years of waves for each country depending on the availability. The time series begins with data observations in the United States in 1974 and ends with the United Kingdom in 1999. Thus we cover aging in the last quarter of the twentieth century.

Table 1 of Appendix A presents cohort ages in each country. For each country, the age of the cohort increases as you move down the table and to the left. The shaded cells indicate that each cohort contains only persons who are at least 65 years of age. Men and women in the oldest cohort for whom we have observations come from the United Kingdom and they are between the ages of 90 and 99 . The youngest people in our sample come from the United States' birth cohort 1920-1929. 


\section{Results}

Because the objective of our research is to present a picture of the change in benefits and income for cohorts over time, we observe six key measures and present them in Figures 1 through Figure 5 in Appendix A. We measure a cohort's well-being across time by charting the cohort's change in poverty rate and income source as the cohort ages, and we make cross-national comparisons within cohorts. In addition, we compare the position of older women to that of the entire population, and compare the status of women who own their home with women who rent in order to assess the asset status of these elders.

\section{III.1. Interest, rent and dividends: The role of property income}

Several interesting characteristics of property income are apparent from Figure 1. First, there is considerable cross-national variation in property income's (interest, rent, and dividends) contribution to net disposable income, and it is particularly true in the older cohorts. The percentage of income received from property income ranges from a low of 1 percent to a high of 34 percent, with the United States representing the low of 1 percent and Canada receiving the high of 34 percent. Women in the United Kingdom receive on average fourteen percent of their income from property income, except in the final wave of data where the oldest cohort experiences a spike in the value and then a decline. Swedish women receive a similar percent of income from interest, rent, and dividends, and Australian women receive the most with a figure of 20 percent, on average.

Second, the path of property income's evolution over time also varies significantly across countries. Take for example the income story of our birth cohort in Panel B as an example. In the United Kingdom and Sweden, property income increases 
by five percentage points and then falls suddenly in the last wave of data. The trend for Canadian and Australian women is flat, but United States women experience a 25 percentage point jump in the value of their income from this source in ten years.

There are several reasons for the variation across countries in the value of property income as a source of income in later life. First, saving behavior is affected by differential preferences in the mix of assets one holds in one's portfolio, and this preference is likely to affect the source of income in later life. For example, in the United Kingdom, where the income from interest, rent, and dividends is relatively low, homeownership is relatively high. A second story that could explain the large differences across countries in the value of income from this source is the effect of the social retirement scheme on saving behavior. Citizens in countries with higher payments from their country's social retirement and transfer programs might feel less inclined to save over their lifetime. As a result, in later life people in Sweden, a country where older men and women rely heavily on retirement income provided by the state, have lower savings.

Finally, and perhaps most importantly for older women's financial well-being, the reliance on property income increases slightly over time. In contrast to the older cohorts, Panel $\mathrm{C}$, the panel with the youngest cohort, displays a tighter grouping of values across countries and time. Over time, the trend is for interest, rent, and dividends to increase in the percentage of DPI as women age in all countries, but from different starting levels. Overall, income from interest, rent, and dividends makes up about 25 percent of DPI in three of our five countries. In Sweden a large percentage of women receive income from interest, rent, and dividends, although it makes up only 10 percent of total DPI. Those in the United Kingdom also receive close to 10 percent of their income from this source, and have a similar rate of receipt across cohorts. For the countries where interest, rent, 
and dividends make up closer to a quarter of DPI, the percentage of women who receive this type of income ranges from 60 to 80 percent.

We conclude that, as a source of income in later life, property income plays a small role overall. But in countries where the level of social retirement benefits is lower relative to other countries in our study, they can make an economic difference in old age. To put the importance of the figures into perspective, those older adults who receive one quarter of their income from interest, rent, and dividends could use this to pay their annual food bill. Further, the perceived generosity of social retirement benefits and social transfer benefits might induce people to not save additional amounts for their retirement; or they may choose to hold assets that do not generate income flows, such as homes.

\section{III.2. Pensions}

In terms of DPI, occupational pensions represent a common income source across countries. Figure 2 presents the value of occupational pensions as a percentage of disposable personal income for each cohort in three panels. Panels A, B, and C compare the change in pension value for each birth cohort of the five countries over a twenty-five year period. For most women in the birth cohorts 1900-1909 and 1910-1919, occupational pensions make up close to 30 percent of DPI. The exception is women from Australia, who have pension values closer to 55 percent of DPI. We also note that Australia is a nation without a contributory social retirement scheme.

Panel $\mathrm{C}$ of Figure 2 emphasizes the rise of pensions as a source of income for the youngest cohort. The cohort born between 1920 and 1929 is still receiving a majority of its income from labor earnings. However, once the cohort reaches 65 years of age, which happens in the mid-1980s, pension values level off at close to 35 percent of DPI. Here again, Australian women have pension values higher than the other countries. As a source 
of income in later life, occupational pensions make up an equal percentage of DPI across all countries but Australia, owing most probably to their lack of a social retirement scheme.

The percentage of women who receive income from occupational pensions grows as the cohorts age, and this is true for all countries, but for the youngest cohort it is particularly noticeable. Figure 2 a documents the change in receipt of occupational pensions. The trend in receipt is likely a result of labor force participation(their own or their husband's via joint and survivor benefits). As more women retire, pension receipt increases steadily. Below, we present Panel B from Figure 2a to highlight the trend in receipt. Here we see that receipt of occupational pensions reaches close to 50 percent by the mid-1980s, a time when the cohort age reaches its mid-60s, which is close to retirement age.

Figure 2a. Percentage who Receive 0ccuopational Pensions

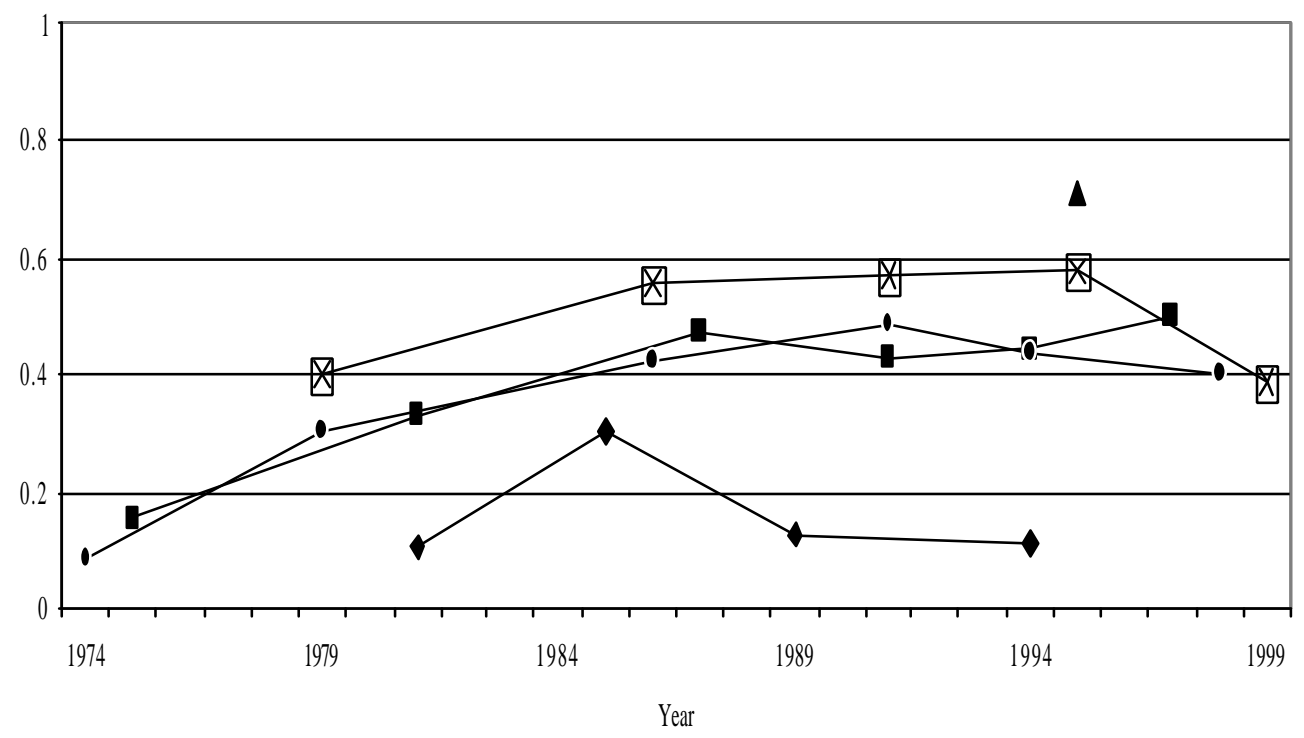

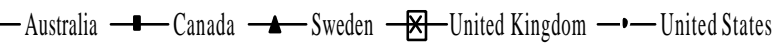

A final feature to note is that Australian women lag all other countries in receipt 
of occupational pensions although their relative dependence on pensions as a source of income is comparatively high. In other words, the few older adults in Australia who do receive occupational pensions rely heavily on them as a source of income. ${ }^{5}$ Finally, an important feature of Figure $2 \mathrm{a}$ is the level of receipt of pensions by the oldest old. The birth cohort 1900-1909 in Panel A has a lower level of receipt than the younger cohorts, and this is likely the result of losing a pension because of the death of a spouse.

\section{III.3. Earnings}

As we expect, the percentage of women receiving any income from labor earnings fell for all countries and all cohorts over time. Panel $\mathrm{C}$ of Figure 3a shows a high percentage of women in the youngest cohort was receiving labor earnings, but as the cohorts reach the age of 65 , labor earnings drop significantly as a source of income. The United States and Canada had the highest number of very old women receiving labor earnings. In contrast, the percentage of those receiving income from labor earnings by the oldest old in Sweden and the United Kingdom is close to zero.

Panel $\mathrm{C}$ of Figure 3 presents a clear picture of falling relative earnings values. For those who receive earnings, the value of earnings makes up close to 100 percent of their income in the 1970s. By 1980, labor earnings start to fall as a percentage of DPI, and by the end of our time series, earnings represent a high of 80 percent for women in the United Kingdom and a low of 6 percent of income for women in Sweden. One interpretation of the figures is that labor earnings are an extremely important component of income for older women in the United Kingdom; if they are working, they receive only 20 percent of their DPI from other sources. On the other hand, Swedish women who work receive most of their DPI from sources other than earnings. 
Panel A of Figure 3 presents the earnings of the oldest cohort. Few women in the United Kingdom work after the age of 65 , but for those who do, earnings make up a significant portion of DPI. Because few Swedish women work, their earnings contribute little to total DPI. In the United States, older women receive 60 percent of their DPI from earnings, a figure that is stable over time.

\section{III.4. Social Retirement}

The importance of social retirement benefits is clear from Figure 4a. For the oldest old in Panel A, receipt is close to 100 percent. Once the entire cohort in each panel reaches 65, well over 90 percent of older women receive some portion of their income from this source.

The panels in Figure 4 track the rise in the value of the benefits as an income source. The upward trend in social retirement value in Panel $\mathrm{C}$ is consistent across all countries; however the relative value of the benefits in the income mix varies. Panel B of Figure 4 below illustrates the rise in value of social retirement benefits.

Figure 4. Social Retirement Benefits as a Percentage of Personal Income

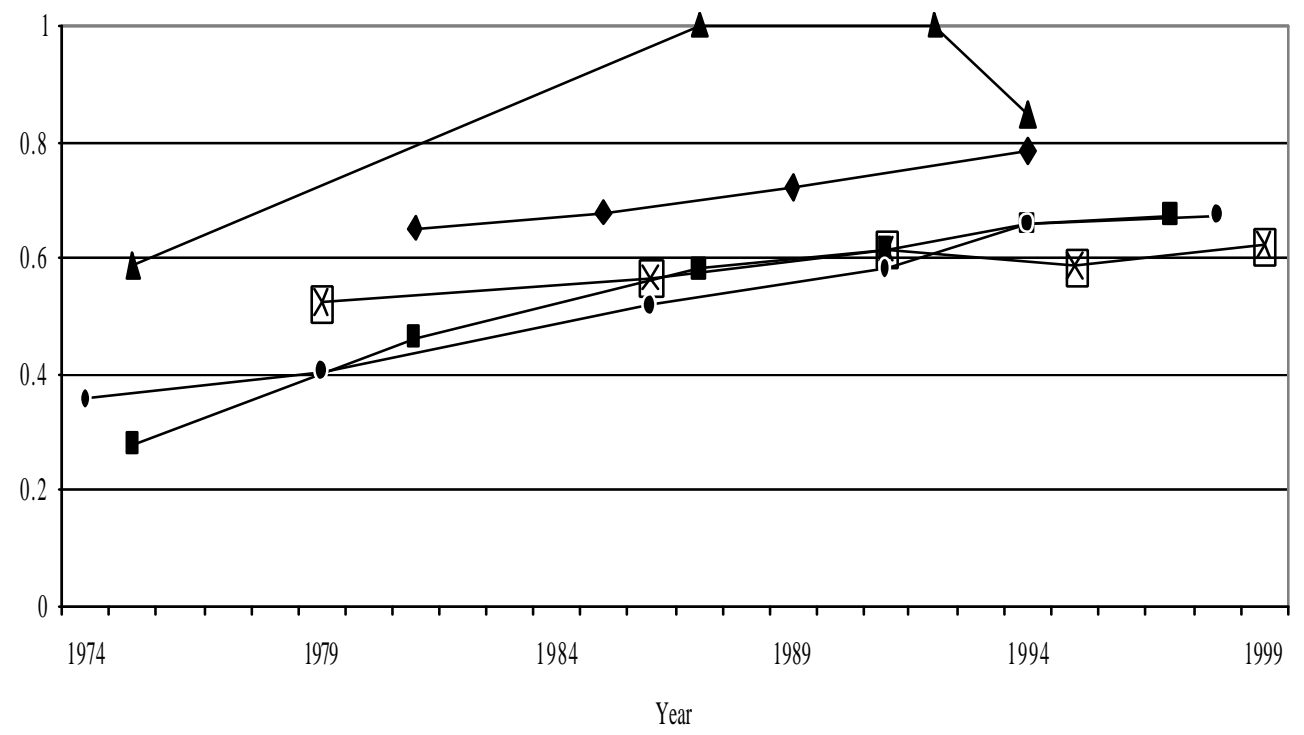

- Australia $\rightarrow$ Canada $\longrightarrow$-Sweden 囚-United Kingdom —-United States 
The general idea from the figure is that a cohort increases it reliance on social benefits as a source of income. The movement reflects retirement, which is the start of the up-take of social retirement benefits and the loss of income from other sources, namely labor earnings. The figure presented in the text also highlights the difference especially between Sweden and the rest of the countries. Once older women in Sweden begin to receive social retirement income, it accounts for nearly all of their income. Conversely, older women in the United States and United Kingdom receive only 60 percent of their income from social retirement sources. The differences between Sweden and the other countries of the study can be attributed to differences in retirement behavior and earlier uptake of social retirement, and to less reliance on other forms of income.

Sweden has the steepest slope as well as the highest relative values. Of the women between the ages of 45 and 49 in the birth cohort 1920-1929 who receive social retirement benefits, 40 percent of their income comes from this source. By the time the entire birth cohort reaches age 65, social retirement benefits account for close to 100 percent of their DPI. The value of social retirement benefits in the other countries is lower by almost 40 percentage points, and Canada, the United States, and the United Kingdom have very similar values across cohorts and across time.

\section{III.5. Social Transfers}

Receipt of any social transfer benefit (social retirement or other type of public benefit) grew for every country. Figure 5a shows older women in Sweden and Canada have the highest level of receipt. More than 80 percent of Swedish women receive some form of social transfer benefit, even in the early years of the study when the cohort age is less than 60. United States women, on the other hand, have lower receipt of this income 
source. Only a quarter of the cohort born between 1920 and 1909 receive income from social transfers.

\section{III.6. Poverty}

The next step in research is to document the change in poverty rates for our three birth cohorts as they age over time. Using a poverty measure that is defined as 50 percent of the median DPI level or below, we present poverty rates for women and men in Figures 6 and 7.

There are three distinguishing features that emerge in our poverty trends. First, Canadian women experience significant declines in their rates of poverty after 1981 . For two Canadian cohorts, less than 10 percent of women are in poverty. This phenomenon is accounted for by the 1980s Canadian policy intervention directly linking low social retirement (Canadian Pension Plan) to the Canadian income-tested benefit (General Income Security Program). This low-cost and highly target-effective scheme produced a rapid and lasting decline in old age poverty (see Osberg 2001; Smeeding and Sandstrom forthcoming; Smeeding and Weaver 2001; Zuberi 2001).

Swedish poverty rates for women are stable over time. The level is close to 5 percent for the birth cohorts 1910-1919 and 1920-1929. The oldest old in Sweden, those born in1900-1909, have poverty rates closer to 10 percent, a figure that is stable over the 20 years of data. Both Swedish social retirement and targeted income support produce this result (Smeeding and Sandstrom forthcoming).

The last trend is less optimistic. Australian, American and British older women have rates of poverty that are rising as the cohorts age and are relatively higher than Canadian and Swedish cohorts. Low levels of first-tier social retirement benefits and low 
take-up of income-tested benefits both account for this result (Smeeding and Williamson 2001).

Swedish men and women have the most similar rates of poverty in the study when we compare poverty by gender. The rate rarely exceeds 10 percent, except for the oldest old in both sexes. On the other hand, as men and women age in the United States, the sex differential in poverty rates increases. United States women in the oldest cohort continue to fall deeper into poverty, while their counterparts have a stable poverty rate below 30 percent. In the three other countries, Australia, Canada, and the United Kingdom, men have lower levels of poverty, but the paths the rates follow are similar.

In Figures 8 and 9 we present poverty levels for those who have incomes that are 40 percent of the overall median DPI or below. We are able to see poverty rates drop significantly for the majority of countries. For example, in Figure 8 Panel C (the youngest cohort), the countries cluster below 10 percent, and the trend remains flat as the cohort ages. The change in poverty rates for older cohorts is similar. The United States still has the highest level of poverty, and the trend in United Kingdom is for the oldest old to fall further into poverty. The poverty level for Australia on the other hand is sensitive to the change in the poverty measure. If we compare Panels A and B in Figure 8 to the same panels in Figure 6, we notice that in some years the poverty rates of older women drop by almost 25 percentage points. Again, however, the poverty of the oldest old is still relatively high compared with the low benchmarks of Canada and Sweden.

Hence, we find that in the majority of the countries in our study, nearly half of the women in poverty have income that is at least 40 percent of the DPI of the population as a whole. The other half are below 40 percent. Second, the rates of poverty over time increase at a slower rate in using the 40 percent measure. The point is best made with a 
comparison of a panel $\mathrm{C}$ from Figure 6 and a panel $\mathrm{C}$ from Figure 8. The rates in the two figures differ markedly. The percentage of women in poverty at the 40 percent level remains fairly constant over time for the countries in our study, however, for the United States, Australia and the United Kingdom, the rates at the 50 percent level rise 10 percentage points or more. The value of the two figures is that they highlight a group of vulnerable women that begin to fall into poverty as the cohort reaches its early to midsixties in age.

Figure 6. Percentage of Women in Poverty: $50 \%$ of the Median Disposable Personal Income

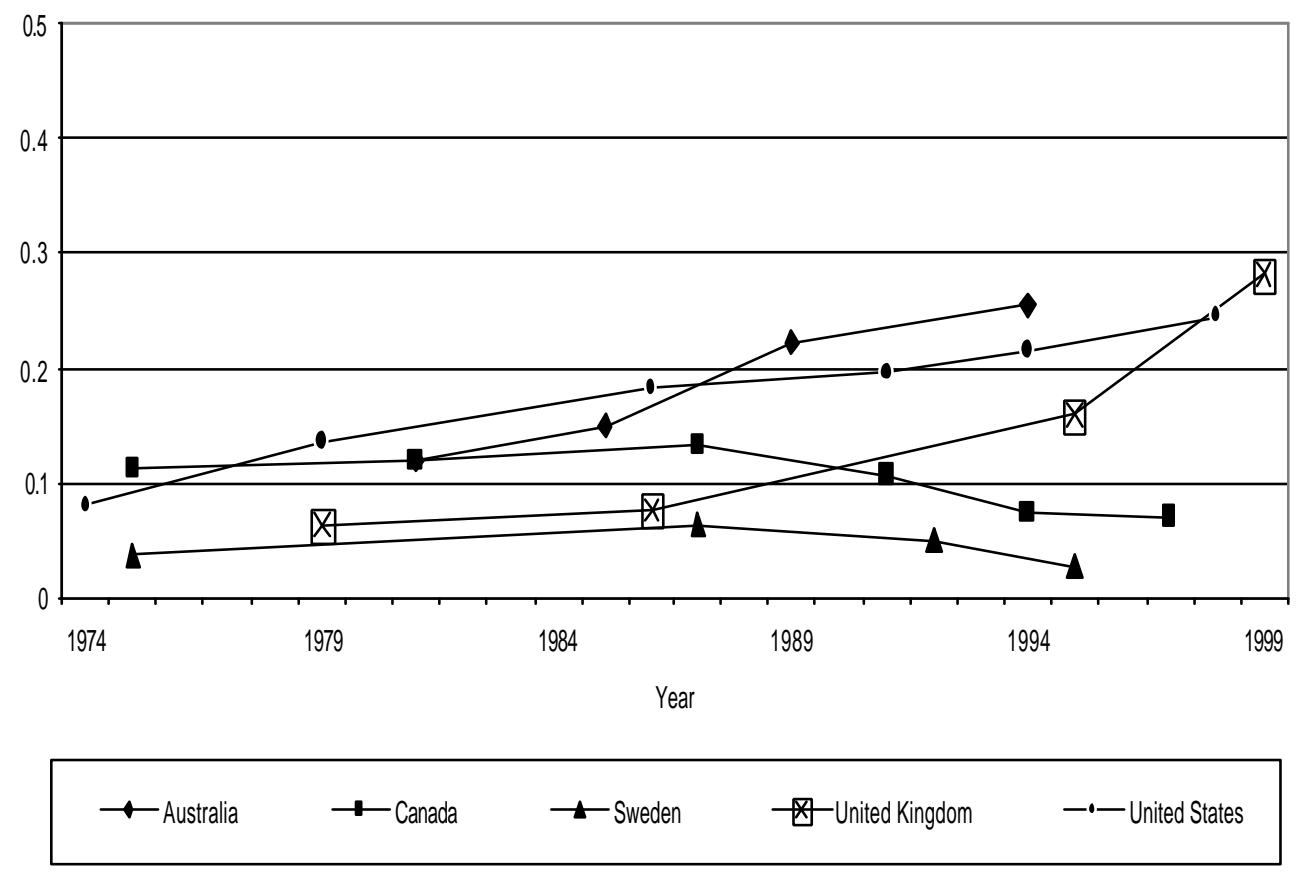


Figure 8. Percentage of Women in Poverty: $40 \%$ of the Median Disposable Personal Income

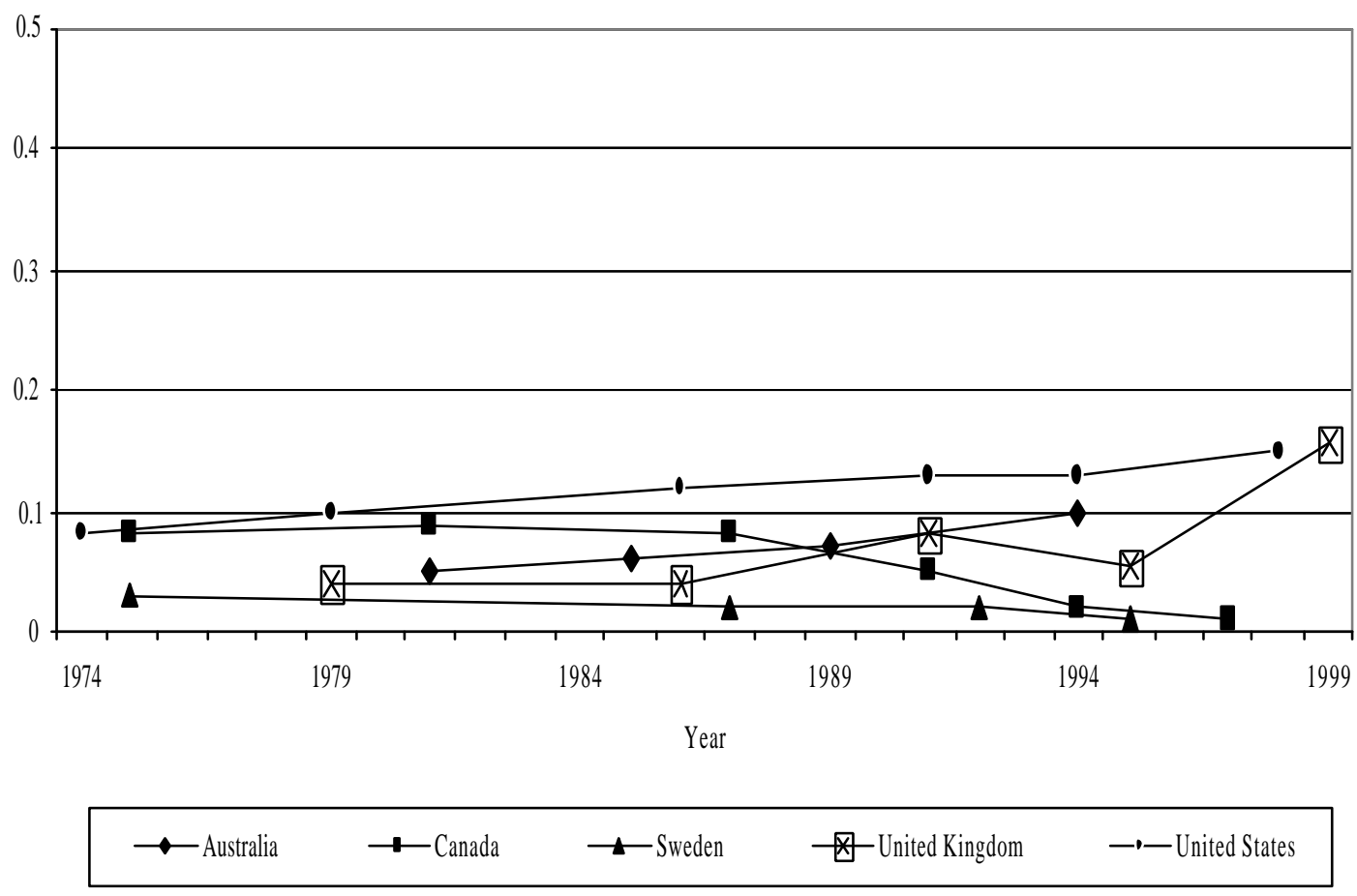

The timing is important because it corresponds to retirement and the uptake of social retirement benefits, as well as the potential loss of a spouse. In contrast, in countries with relatively generous social retirement benefits, Canada and Sweden, the poverty rates fall over time. As the cohort moves past 65 years of age, the poverty levels for the two countries begin to drop.

The poverty rates of men do not change as much when we lower the poverty threshold. If we compare the rates of men in Figure 9 with the rates of women in Figure 8 , we can see the difference in poverty rates is not as pronounced as it is under the 50 percent median DPI measure. The poverty rates for United States and United Kingdom men differ by less than 10 percentage points among the oldest old. These results are consistent with cross-sectional levels of poverty among the aged in other LIS studies (Yamada and Casey 2002; Smeeding and Sandstrom forthcoming). 


\section{III.7. Comparison of homeowners and renters in old age}

In this section, we highlight the differences between homeowners and renters in terms of DPI and poverty rates. Renters are defined people who are non-homeowners. Renters either report paying rent in a dwelling or living in someone's dwelling, but not owning the home. Figure 11 plots the relative median DPI for groups, renters and homeowners, as well as for each birth cohort. In the United States, we see older women who rent have lower levels of median DPI than homeowners for each cohort. However, Figure 10 shows that women who own a residence accelerate into poverty more quickly than women who are renters, and by the time each cohort reaches the age of sixty five, the poverty rate for renters is twice as high as the poverty rate for homeowners. Poverty is measured as having a median DPI that is 50 percent or less of the overall median DPI of the entire population.

In the United Kingdom, each cohort of homeowners falls into poverty at a rate that is much slower than renters. In fact, the slope for homeowners is close to half the slope of renters. The trend in relative DPI for homeowners and renters diverges as the two groups age, and Figure 11 shows the divergence that takes place in 1979. We see from the slope values in Table 2 that incomes for cohorts of homeowners rise just as quickly as incomes of renters drop.

Counter to the experience of older women in the United Kingdom but like the experience of women in the United States, Australian older women who are homeowners fall into poverty at a higher rate than renters do. Figure 10 documents the rise in poverty of both renters and homeowners. Unlike the experience in the United States, however, homeowners have a relatively high level of poverty compared to renters. Women in the birth cohorts 1900-1909 and 1910-1919 who are homeowners have higher levels of 
poverty. The trend in disposable income for older women in Australia is similar to the United States and United Kingdom. Renters' and homeowners' incomes both decline as the cohort ages, and like the United States, incomes decline for homeowners more quickly.

Overall, Canadian women demonstrate a gentle progression out of poverty as they age. In fact, women who are renters have a negative slope value in all panels of Figure 10. Homeowners for the most part show a downward trend in their poverty; however, the slope values are close to zero. With respect to levels of poverty, homeowners have a lower level of overall poverty than renters in each cohort, with the difference ranging from between five and seventeen percentage points. This is true for most countries in our study. Disposable personal income falls for most women, and falls more quickly for homeowners. Like other countries, the level of disposable personal income is higher for homeowners. A notable feature in the Canadian system is the institution of the GIS in 1981. The GIS appears to have slowed the decline in disposable personal income and may be the reason we see poverty rates fall after 1981 for renters in particular (Osberg 2001; Zuberi 2001).

Older women in Sweden have overall poverty rates that are significantly lower than the older women in the other countries. Generally, the poverty level for older women who own homes is close to 3 percent. For renters, the poverty rate is higher by between four and thirteen percentage points. For the three cohorts of homeowners, poverty rates decline slowly as they age, while renters slowly fall into poverty at rate similar to United States women. Disposable income of renters and homeowners follow similar trends over time and the slope values confirm what Figure 11 suggests. Overall, homeowners again have higher incomes, and the difference between the two groups is consistently small. 


\section{Conclusion and Comments}

We have carefully examined the level and mix of private income and social benefits for older women in the five countries. As we have seen, social retirement and other social transfer benefits make up a large percentage of the income mix of the oldest old across all five countries in our study, and the importance of these benefits grew as a source of total disposable income as our synthetic cohorts aged. Social retirement benefits accounted for nearly 60 percent of the income of those who receive these benefits and in the oldest cohort receipt is close to 100 percent. For the older women in the United States these benefits made up nearly 70 percent of their DPI, which is slightly higher than the United Kingdom and Canada, but much lower than Sweden.

In the United States, the oldest old received most of their income from social retirement benefits. Other social transfer benefits added another 20 percent to the mix of income provided by the state, and together they accounted for most of the income of older women. These social transfers were means tested and usually affected the younger cohorts in our study more than the older ones. The figures make it clear that the policies regarding social retirement and income maintenance have a large impact on the financial well-being of older adults, especially older women.

The income figures from private sources also tell a story about the changing role of labor earnings and private wealth in an older woman's income package. As we would expect, labor earnings as a source of income fell for the youngest cohort (years 19201929) as it aged. When the cohort was under 60 years of age it had a labor force participation rate that was slightly above 60 percent, but it declined steadily as the cohort aged past 65 . The older cohorts in our study had already aged past 65 and therefore had low levels of labor force participation when we began observing them. For the few older 
women who still worked, labor earnings made up one-half of total DPI; a pattern that was true for all countries but Sweden. Occupational pension income was a much more important income source for the youngest women in our study. It accounted for approximately 40 percent of DPI, and receipt ranged from 60 to 75 percent at its highest. The value of occupational pensions to women's incomes in the United States relative to the other countries in our study remained constant over the three panels, aside from the outlier values from Australia. The United States' values matched those of Canada, Sweden and the United Kingdom in terms of percentage of DPI and in terms of the rate of uptake as women retired. The oldest cohort of women relied on occupational pension income for a smaller percentage of their DPI, but only 40 percent received any income from this source. In the United States, approximately 35 percent of women over the age of 65 received any income from occupational pensions. The United Kingdom stands out as the country in which receipt of occupational pension was relatively high. In the United Kingdom, 70 percent of the women from the youngest cohort reported receiving at least some income from this source, though the figure declined for older cohorts. However, it remained 5 to 10 percentage points higher than the rest of the countries.

Finally, income from assets that generate interest, rent, and dividends remained a steady percentage of DPI across time and cohorts. Although receipt of income from property income was consistently high across all countries and cohorts, ranging from between 60 and 80 percent of the cohort, property income made up less than 30 percent of net DPI. And in the United States property income generated just over 20 percent of DPI and in Sweden the figure was closer to 10 percent. In terms of importance as an income source, interest, rent, and dividends played a minor role in the financial status of older women. One factor responsible for the relatively low value of property could be 
that wealth is held in other forms. Particularly in the United States, wealth held in the form of housing may explain the low figure on this set of assets. Another is health events that required large out-of-pocket spending. The implication of the low value of asset wealth is that the most vulnerable older women rely heavily on other sources of income from the total mix, particularly socially provided income transfer benefits.

When we considered the relative positions of homeowners and renters, we saw that homeowners were universally better off. Homeowners had higher relative DPIs tha n renters, and in some countries, the trend in income diverged over time; homeowners become richer and renters became poorer.

It is evident that homeowners are falling into poverty at a lower rate than renters, and in many cases, even rising out of poverty. In the United States and Australia, the trend in poverty increased for both, but accelerated faster for renters. On the other hand, poverty rates declined for homeowners and renters in Canada. Whether homeownership provides income security to older women or rather older women with higher incomes are just more likely to own their home is a question for further study, but in our research homeownership was associated with lower poverty.

When we looked at the overall poverty rate, poverty rose in Australia, the United States, and the United Kingdom for men and women as the cohorts aged, but women had rates that were higher by as much as 25 percentage points. By changing the poverty measure to 40 percent of the median DPI, in essence lowering the bar, we found almost half of the women in poverty were raised out of it. Further, the difference in poverty rates between men and women was almost eliminated as a result of the change in metric.

In the end we found the countries with the best record on poverty, Canada and Sweden, were the countries that had instituted higher replacement rates for their social 
transfers programs, albeit for different reasons. In Sweden, the reason was a long-term labor force attachment and combined tiers of social retirement. In Canada, the most important factor accounting for the difference in poverty rates of older adults between Canada and the rest (e.g., United States and Australia) was their social retirement benefits programs. The institution of the Guaranteed Income Supplement (GIS) in Canada effectively created a floor below which incomes for older adults could not fall, and as a result, we saw the poverty rates fall sharply in the early 1980s, especially for women. Finally, the exercise of changing the poverty thresholds provided evidence that targeted transfers to help the very poor can achieve large results. If governments raise the incomes of the very poor by 10 percent, in the case of very old women, poverty can be reduced by 25 percent.

If Australia, the United States, and the United Kingdom hope to reduce poverty rates among their older citizens, a first step is to reconsider how to insure people against extended old age. The issue of income decay and heavy reliance on social retirement and transfer benefits becomes particularly important for the oldest old, and there are several ways in which these countries could help their oldest citizens. Higher indexation of survivor benefits is one example. The Canadian GIS, for instance, better insured against extended old age by raising the rate of indexation for social retirement and transfer benefits.

In a simulation experiment, Rupp, Strand, and Davies (2003) and Davies and Favreault (2004) assess the efficacy of changes to the major United States targeted income transfer program--Supplemental Security Income (or SSI). The goal of their exercise is to help reduce poverty among older adults, especially for older women They show how modifications to benefit rates (income guarantees) for single older adults 
(primarily women), increasing the general income exclusion and Social Security income exclusion, and changes to the asset threshold could possibly raise older adults out of poverty. However, these changes would have to be substantial to overcome take-up proble ms and low liquid asset qualification levels. But if so enacted, the additional SSI benefits generated by such changes would accrue primarily to older women suggesting that the simulated program modifications are generally well-targeted.

Another solution would be the promotion of investment in private annuities by older adults. Such an annuity could supplement other forms of retirement income, and would act as an insurance policy against outliving private income and savings.

The bottom line is that poverty in old age is exacerbated by either inadequate private income or low social benefits or both. The way in which each country deals with the issue will ultimately reflect whether it believes it is a private or public responsibility to care for an aging society. 


\section{References}

Atkinson, Anthony B., Lee Rainwater, and Timothy M. Smeeding. 1995. "Income Distribution in OECD Countries: Evidence from the Luxembourg Income Study (LIS)." Social Policy Studies No. 18. Paris: Organization for Economic Cooperation and Development. October.

Burkhauser, Richard V., Philip Giles, Dean R. Lillard, and Johannes Schwarze. 2003. "After Death Do Us Part: An Analysis of the Economic Well being of Widows in Four Countries." Unpublished manuscript. Cornell University, Ithaca, NY. September.

Burkhauser, Richard V., and Timothy M. Smeeding. 2001. "The Role of Micro-level Panel Data in Policy Research.” Schmollers Jahrbuch 121 (3): 1-32.

Butrica, Barbara A., Karen Smith, and Eric Toder. 2002. "Projecting Poverty Rates in 2020 for the 62 and Older Population: What Changes Can We Expect and Why." CRR WP \#2002-03. Chestnut Hill, MA: Center for Retirement Research, Boston College. September. http://www.bc.edu/centers/crr/papers/wp_2002-03.pdf.

Davies, Paul S., and Melissa M. Favreault. 2004. "Interactions Between Social Security Reform and the Supplemental Security Income Program for the Aged." CRR Working Paper No. 2004-02. Chestnut Hill, MA: Center for Retirement Research, Boston College. February. http://www.bc.edu/crr/papers/wp_2004-02.pdf.

Feldstein, Martin. 2004. "Reducing the Risk of Investment Based Social Security Reform." Paper presented at the SSA Retirement Research Consortium Annual Conference, "The Future of Social Security," in Washington, DC, August 12-13.

Hungerford, Thomas L. 2002. "Is There an American Way of Aging?: Income Dynamics of the Elderly in the U.S. and Germany." Working Paper No. 365. Annandale-onHudson, NY: Levy Economics Institute of Bard College. December.

Immervoll, Herwig. 2004. "German Benefit Changes." Paris: Organization for Economic Cooperation and Development. September 28.

Jackson, Richard, and Neil Howe. 2003. "The 2003 Aging Vulnerability Index: An Assessment of the Capacity of Twelve Developed Countries to Meet the Aging Challenge." Washington, DC: Center for Strategic and International Studies. March. http://www.csis.org/gai/aging_index.pdf.

Kalman, Rupp, Alexander Strand, and Paul S. Davies. 2003. "Poverty among Elderly Women: Assessing SSI Options to Strengthen Social Security Reform.” Journals of Gerontology 58B (6) (November): S369-S368.

Lynch, Julia. 2001. "The Age-Orientation of Social Policy Regimes in OECD Countries." Journal of Social Policy 30 (3) (July): 411-436.

Organization for Econo mic Cooperation and Development. 1998. Maintaining Prosperity in an Ageing Society. OECD Code 031998051P1. Paris: OECD.

Osberg, Lars. 2001. "Poverty among Senior Citizens: A Canadian Success Story in International Perspective.” LIS Working Paper 274. Syracuse, NY: Center for Policy Research, Syracuse University. September. http://www.lisproject.org/publications/liswps/274.pdf. 
Smeeding, Timothy M., and Dennis H. Sullivan. 1998. "Generations and the Distribution of Economic Well-Being: A Cross-National View." American Economic Review, Papers and Proceedings 88 (2) (May): 254-258.

Smeeding, Timothy M. 1999. "Social Security Reform: Improving Benefit Adequacy and Economic Security for Women." Center for Policy Research, Policy Brief No. 16. Syracuse, NY: Syracuse University. http://wwwcpr.maxwell.syr.edu/pbriefs/pb16.pdf.

Smeeding, Timothy M., and R. Kent Weaver. 2001. "The Senior Income Guarantee (SIG): A New Proposal to Reduce Poverty among the Elderly." Unpublished manuscript. Center for Policy Research. Syracuse University, Syracuse, NY.

Smeeding, Timothy M., and James Williamson. 2001. "Income Maintenance in Old Age: What Can Be Learned from Cross-National Comparisons." Luxembourg Income Study Working Paper No. 263. Syracuse, NY: Center for Policy Research, Syracuse University. http://www.lisproject.org/publications/liswps/263.pdf.

Smeeding, Timothy M., and Susanna Sandstrom. forthcoming. "Poverty and Income Maintenance in Old Age: A Cross-National View of Low Income Older Women." Feminist Economics.

Steuerle, C. Eugene, Melissa Favreault, and Frank J. Sammartino (editors). 2002. Social Security and the Family: Addressing Unmet Needs in an Underfunded System. Washington: Urban Institute Press.

Sundén, Annika. 2004. "How Do Individual Accounts Work in the Swedish Pension System.” CRR Brief No. 22. Chestnut Hill, MA: Center for Retirement Research, Boston College. August. http://www.bc.edu/centers/crr/issues/ib_22.pdf.

Yamada, Atsuhiro. 2002. "The Evolving Retirement Income Package: Trends in Adequacy and Equality in Nine OECD Countries." Labour Market and Social Policy Occasional Paper No. 63. DEELSA/ELSA/WD(2002)7. Paris: Organization for Economic Cooperation and Development. September 13.

Yamada, Atsuhiro, and Bernard Casey. 2002. "Getting Older, Getting Poorer? A Study of the Earnings, Pensions, Assets and Living Arrangements of Older People in Nine Countries.” Luxembourg Income Study Working Paper No. 314. Syracuse, NY: Center for Policy Research, Syracuse University. April. http://www.lisproject.org/publications/liswps/314.pdf.

Zuberi, Dan. 2001. "Transfers Matter Most: How Changes in Transfer Systems of Canada and the United States Explain the Divergence in Household Poverty Levels from 1974-1994.” LIS Working Paper No. 271. Syracuse, NY: Center for Policy Research, Syracuse University. May. http://www.lisproject.org/publications/liswps/271.pdf. 


\section{Endnotes}

1. For more on LIS, see www.lisproject.org.

2. This equivalence scale suggests that if a poverty line for an elderly couple is 100 , the poverty line for a single person or a surviving spouse is 70 , reflecting the diseconomies of scale in one vs. two person households.

3. For more on LWS, see www.lisproject.org/lws.htm.

4. For a similar analysis of a single cohort aging over a ten-year period in three nations, see Burkha user et al. (2003).

5. Interestingly, Australia began a mandatory national contributory pension in 1993 to complement their general revenue financial income-tested old-age benefit. They therefore adopted a contributory pension model, not a "pay-as-you-go" social pension model. 


\section{Appendix A}

Table 1

Ages of Birth Cohorts

\begin{tabular}{|c|c|c|c|c|}
\hline \multirow[b]{3}{*}{ Country } & \multirow[b]{3}{*}{ Year } & \multicolumn{3}{|c|}{ Birth Cohort } \\
\hline & & 1900-1909 & 1910-1919 & $1920-1929$ \\
\hline & & & Age & \\
\hline \multirow[t]{4}{*}{ Australia } & 1981 & $72-81$ & $62-71$ & $52-61$ \\
\hline & 1985 & $76-85$ & $66-75$ & $56-65$ \\
\hline & 1989 & $80-89$ & $70-79$ & $60-69$ \\
\hline & 1994 & $85-94$ & $75-84$ & $65-74$ \\
\hline \multirow[t]{6}{*}{ Canada } & 1975 & $66-75$ & $56-65$ & $46-55$ \\
\hline & 1981 & $72-81$ & $62-71$ & $52-61$ \\
\hline & 1987 & $78-87$ & $68-77$ & $58-67$ \\
\hline & 1991 & $82-91$ & $72-81$ & $62-71$ \\
\hline & 1994 & $85-94$ & $75-84$ & $65-74$ \\
\hline & 1997 & $88-97$ & $78-87$ & $68-77$ \\
\hline \multirow[t]{4}{*}{ Sweden } & 1975 & $66-75$ & $56-65$ & $46-55$ \\
\hline & 1987 & $78-87$ & $68-77$ & $58-67$ \\
\hline & 1992 & $83-92$ & $73-82$ & $63-72$ \\
\hline & 1995 & $86-95$ & $76-85$ & $66-75$ \\
\hline \multirow[t]{5}{*}{ United Kingdom } & 1979 & $70-79$ & $60-69$ & $50-59$ \\
\hline & 1986 & $77-86$ & $67-76$ & $57-66$ \\
\hline & 1991 & $82-91$ & $72-81$ & $62-71$ \\
\hline & 1995 & $86-95$ & $76-85$ & $66-75$ \\
\hline & 1999 & $90-99$ & $80-89$ & $70-79$ \\
\hline \multirow[t]{6}{*}{ United States } & 1974 & $65-74$ & $55-64$ & $45-54$ \\
\hline & 1979 & $70-79$ & $60-69$ & $50-59$ \\
\hline & 1986 & $77-86$ & $67-76$ & $57-66$ \\
\hline & 1991 & $82-91$ & $72-81$ & $62-71$ \\
\hline & 1994 & $85-94$ & $75-84$ & $65-74$ \\
\hline & 1997 & $88-97$ & $78-87$ & $68-77$ \\
\hline
\end{tabular}

Source: Authors' calculations from the Luxembourg Income Study. 
Table 2

Slopes of relative DPI

\begin{tabular}{|c|c|c|c|}
\hline Country & Birth Cohort & Renters & Homeowners \\
\hline \multirow[t]{3}{*}{ Australia } & (1) & -- & -- \\
\hline & (2) & -0.0496 & 0.0226 \\
\hline & (3) & -0.0554 & -0.0034 \\
\hline \multirow[t]{3}{*}{ Canada } & (1) & -0.0545 & 0.0229 \\
\hline & (2) & -0.0483 & -0.1073 \\
\hline & (3) & -0.0420 & -0.0810 \\
\hline \multirow[t]{3}{*}{ Sweden } & (1) & 0.0396 & 0.0796 \\
\hline & (2) & 0.0396 & 0.0923 \\
\hline & (3) & 0.0389 & -0.0002 \\
\hline \multirow[t]{3}{*}{ United Kingdom } & (1) & 0.0052 & -0.0301 \\
\hline & (2) & 0.0052 & -0.0218 \\
\hline & (3) & 0.0052 & -0.0345 \\
\hline \multirow[t]{3}{*}{ United States } & (1) & -0.0031 & -0.0304 \\
\hline & (2) & -0.0253 & -0.0720 \\
\hline & (3) & -0.0490 & -0.1022 \\
\hline
\end{tabular}

Source: Authors' calculations from the Luxembourg Income Study.

Note: Women in Birth Cohort (1) were born in the years 1900-1909;

(2) in the years 1910-1919; (3) in the years 1920-1929. 
Table 3

Slopes of change in poverty rates

\begin{tabular}{|c|c|c|c|}
\hline Country & Birth Cohort 1 & Renters & Homeowners \\
\hline \multirow[t]{3}{*}{ Australia } & (1) & -- & -- \\
\hline & (2) & -0.03700 & -0.00600 \\
\hline & (3) & -0.02850 & -0.00450 \\
\hline \multirow[t]{3}{*}{ Canada } & (1) & -0.01200 & -0.01300 \\
\hline & (2) & -0.03220 & -0.00320 \\
\hline & (3) & -0.03030 & -0.00610 \\
\hline \multirow[t]{3}{*}{ Sweden } & (1) & -0.02850 & -0.00650 \\
\hline & (2) & -0.02850 & -0.00450 \\
\hline & (3) & -0.03700 & -0.00600 \\
\hline \multirow[t]{3}{*}{ United Kingdom } & (1) & 0.0146 & 0.00190 \\
\hline & (2) & 0.0144 & 0.01110 \\
\hline & (3) & 0.0144 & -0.00600 \\
\hline \multirow[t]{3}{*}{ United States } & (1) & 0.01040 & 0.02930 \\
\hline & (2) & 0.02380 & 0.02110 \\
\hline & (3) & 0.02380 & 0.02380 \\
\hline
\end{tabular}

Source: Authors' calculations from the Luxembourg Income Study.

Note: Women in Birth Cohort (1) were born in the years 1900-1909;

(2) in the years 1910-1919; (3) in the years 1920-1929. 
Figure 1

Interest, Rent, and Dividends as a percentage of disposable personal income

Panel A: 1900-1909

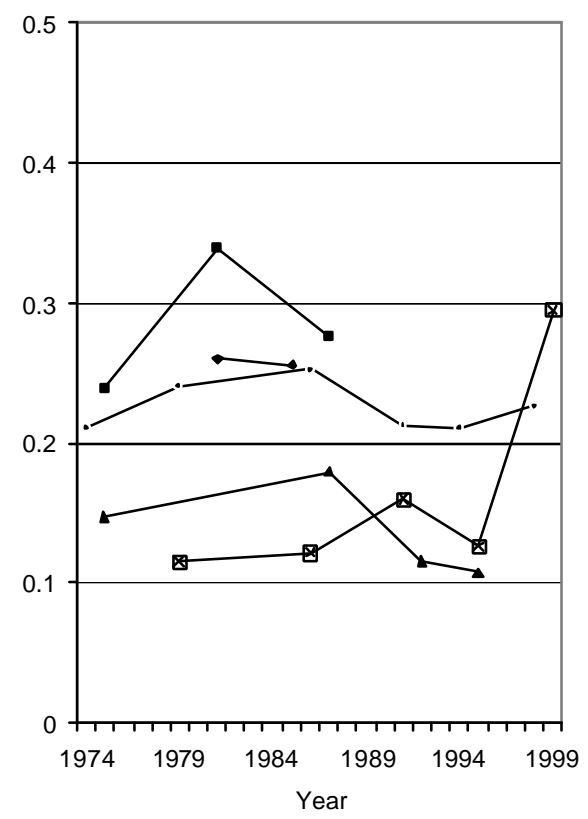

Panel B: 1910-1919

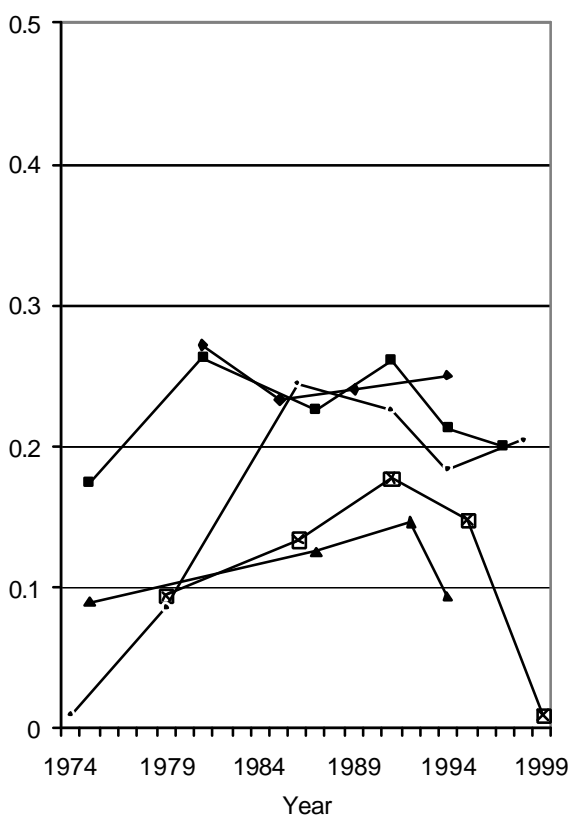

Panel C: 1920-1929

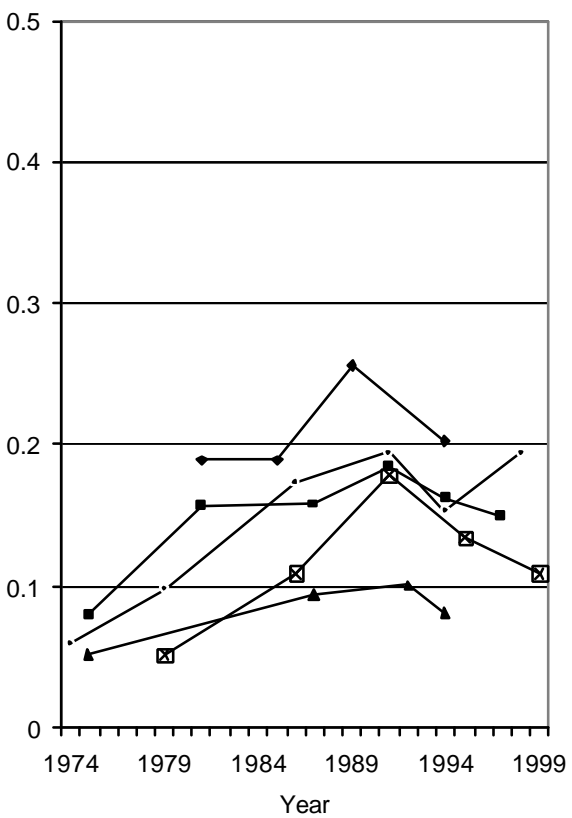

Figure 1a

Percentage who receive interest, rent, and dividends

Panel A: 1900-1909

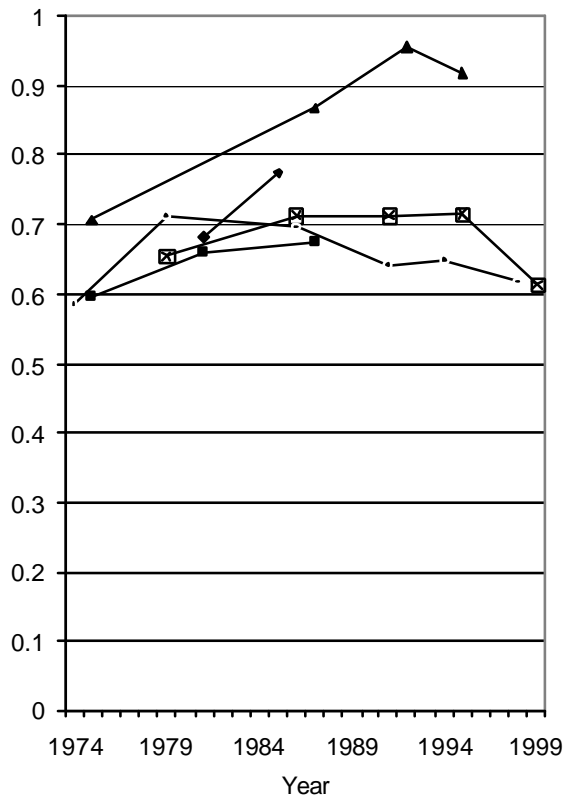

Panel B: 1910-1919

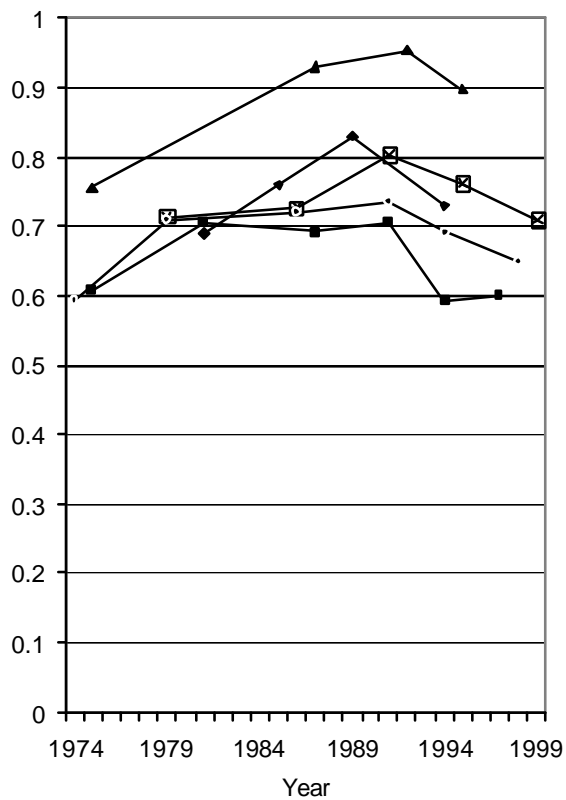

Panel C: 1920-1929

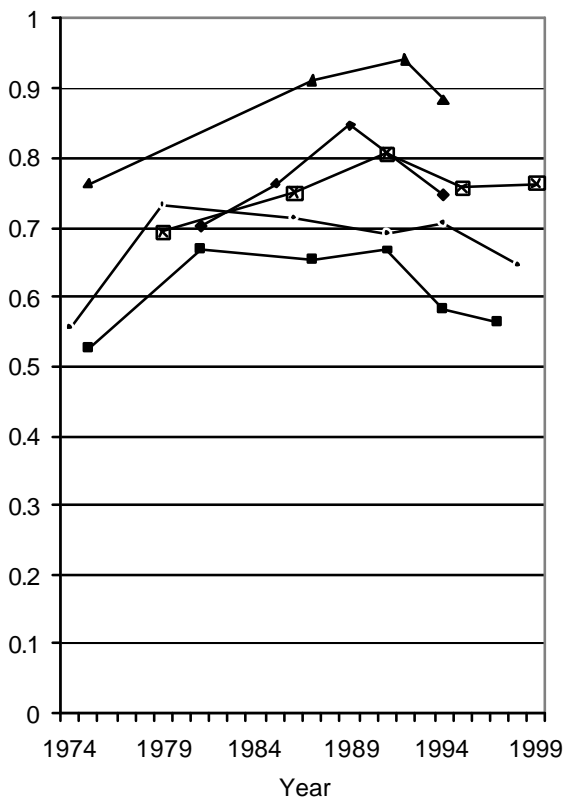


Figure 2

Occupational pensions as a percentage of disposable income

Panel A: 1900-1909

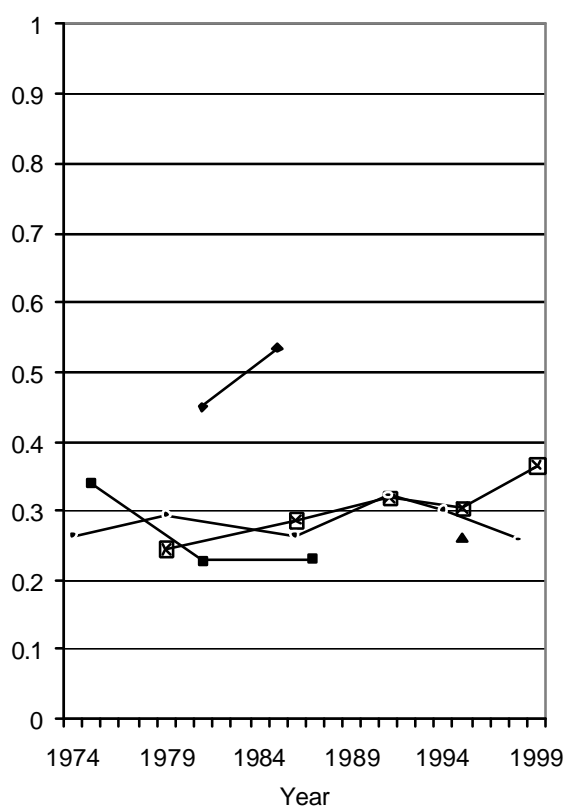

Panel B: 1910-1919

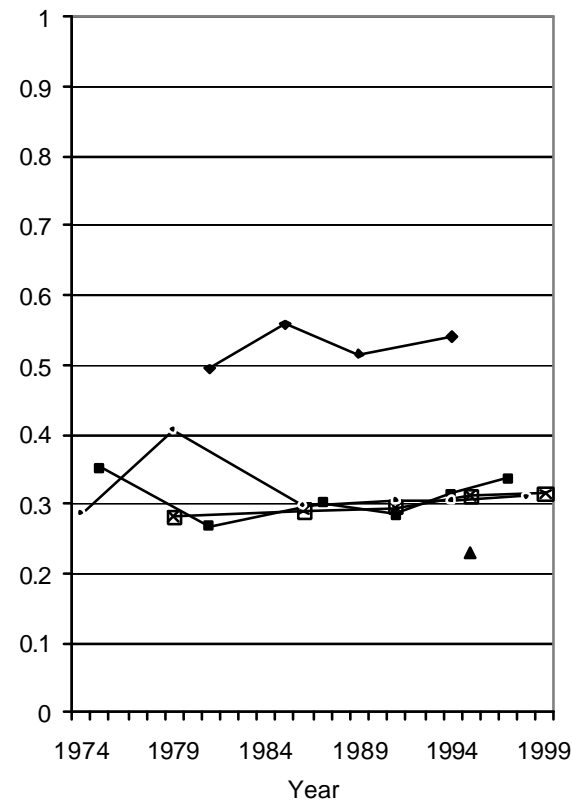

Panel C: $1920-1929$

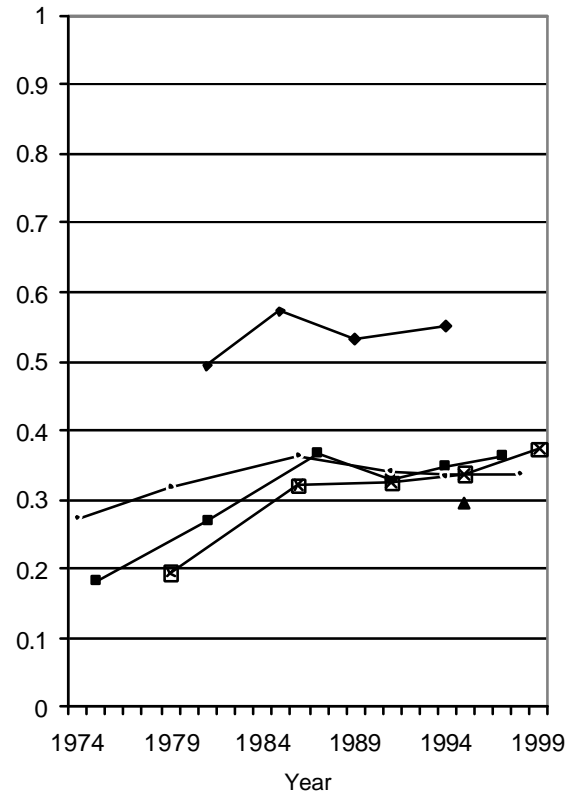

Figure 2a

Percent who receive occupational pensions

Panel A: 1900-1909

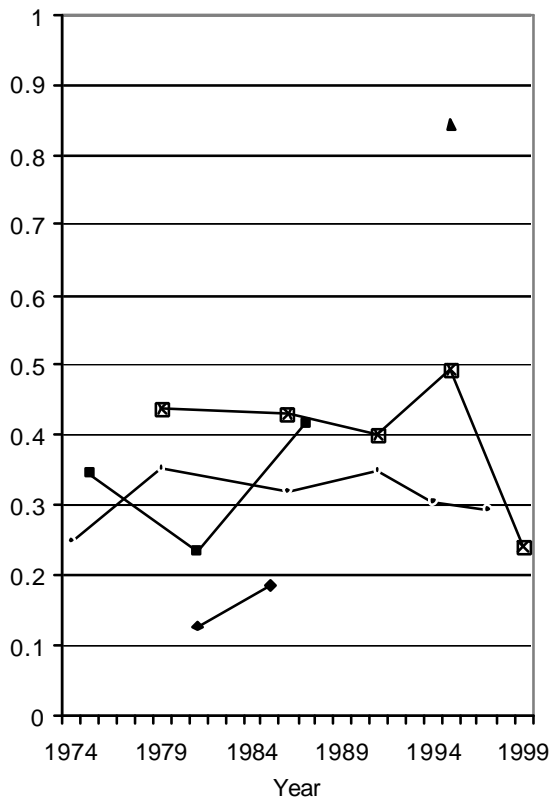

Panel B: 1910-1919

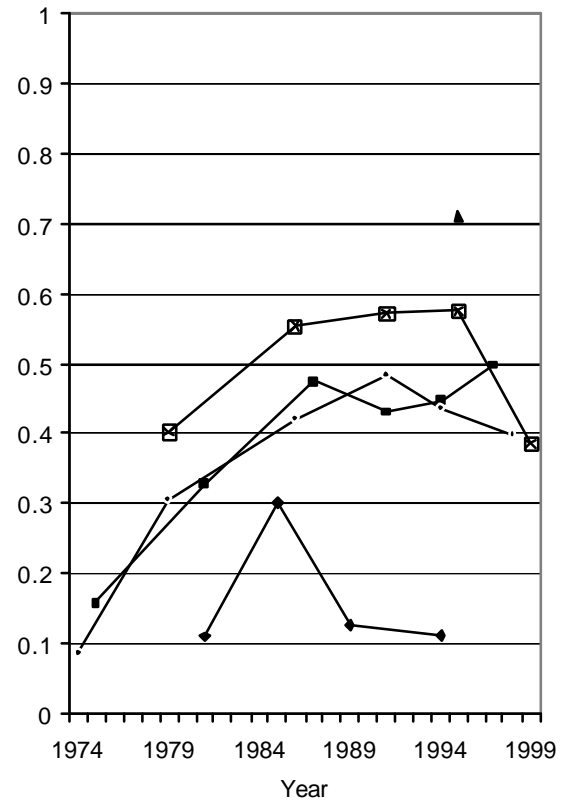

Panel C: $1920-1929$

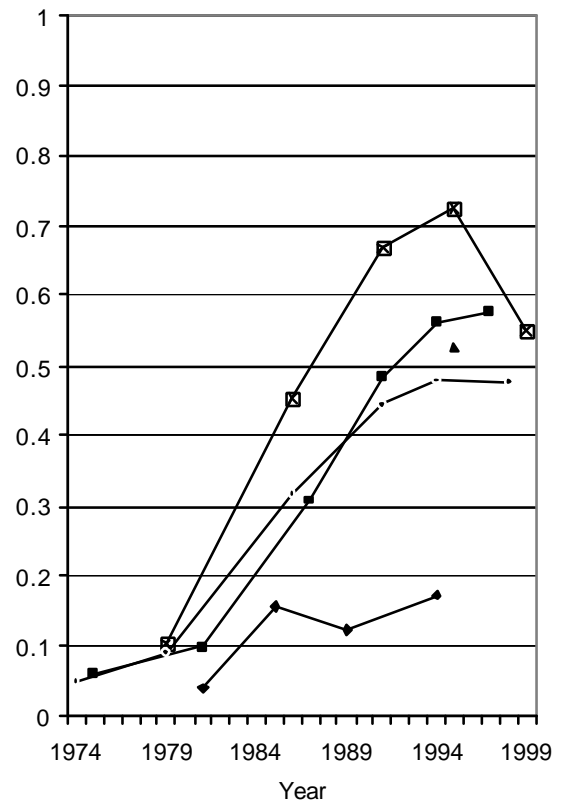


Figure 3

Labor earnings as a percentage of personal disposable income

Panel A: 1900-1909

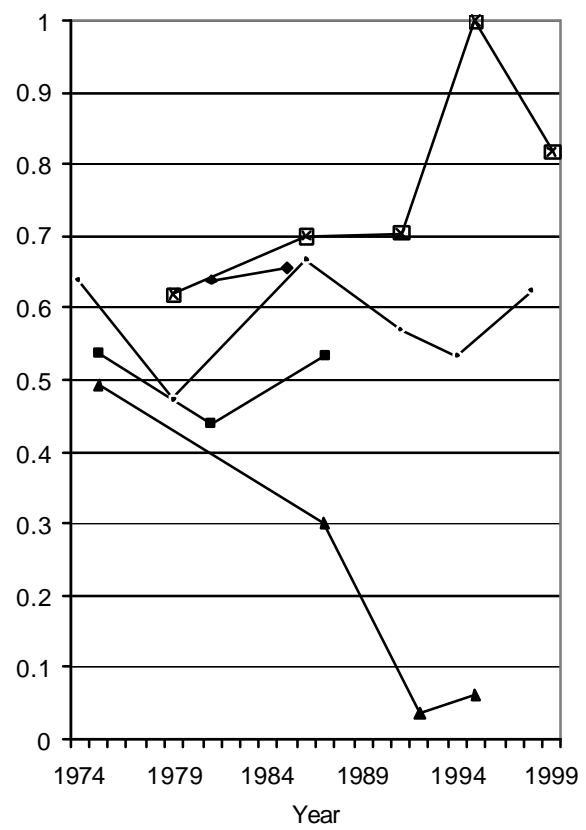

Figure 3a

Percent who receive labor earnings

Panel A: 1900-1909

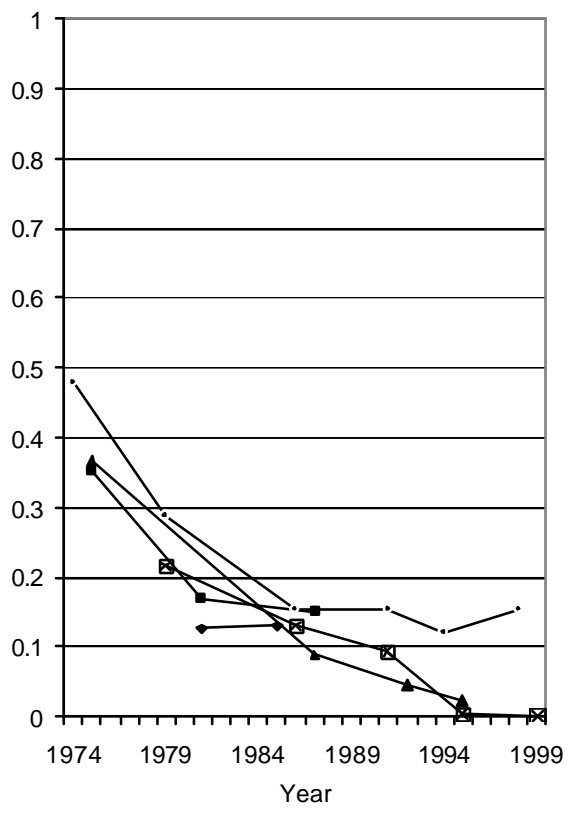

Panel B: 1910-1919

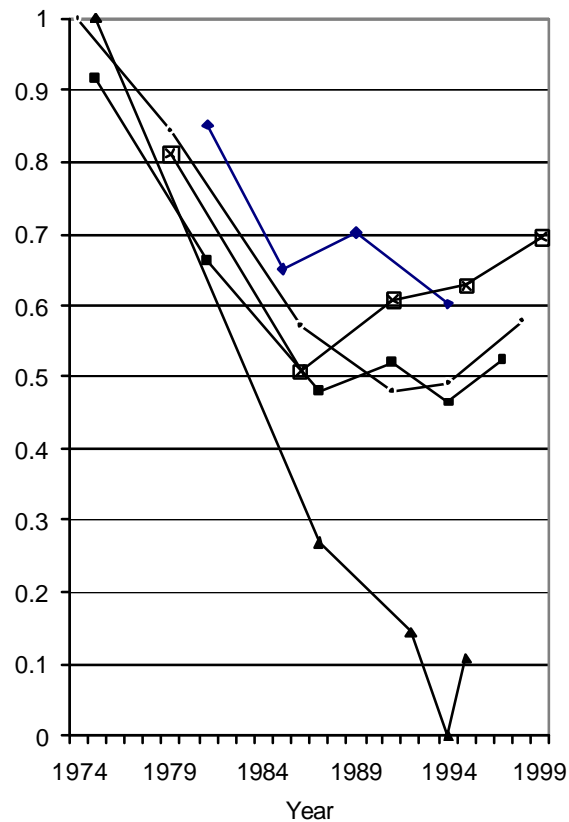

Panel C: 1920-1929

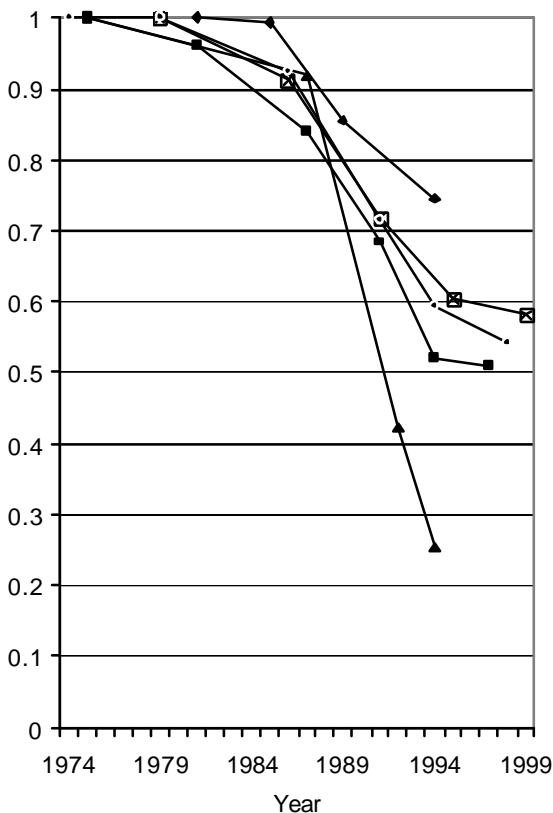

Panel B: 1910-1919

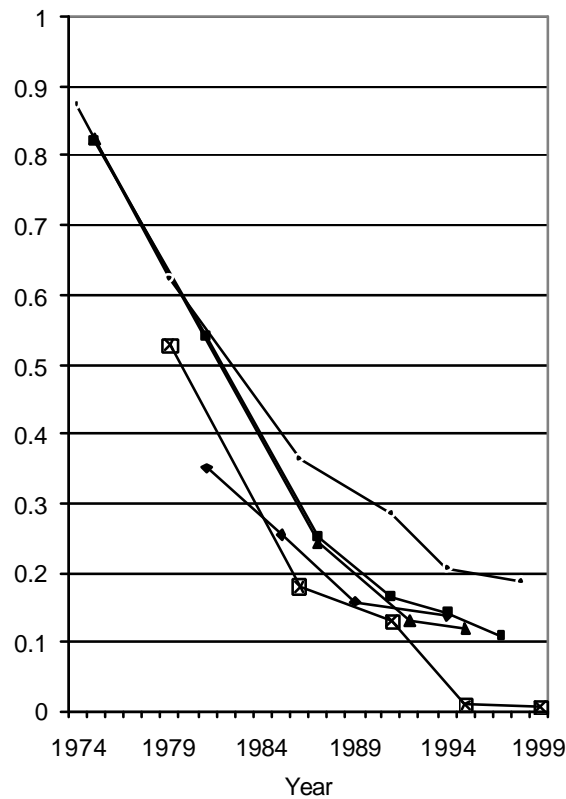

Panel C: 1920-1929

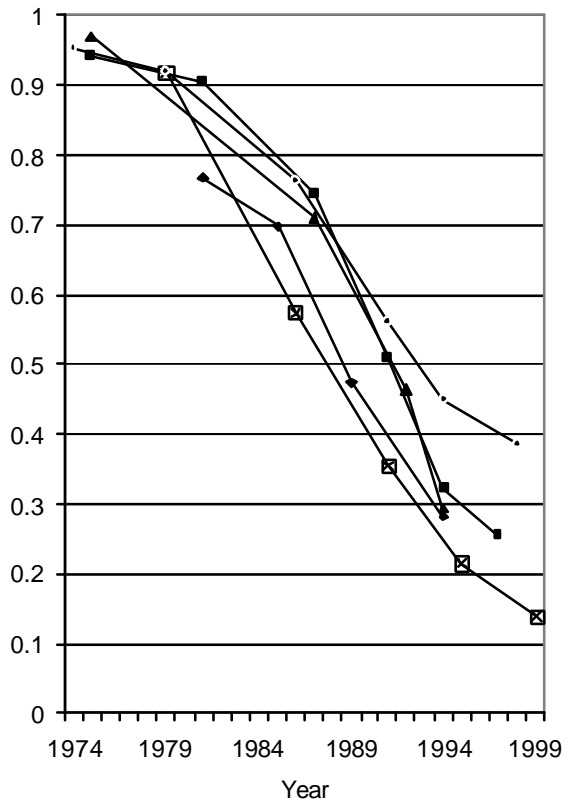


Figure 4

Social retirement benefits as a percentage of personal disposable income

Panel A: 1900-1909

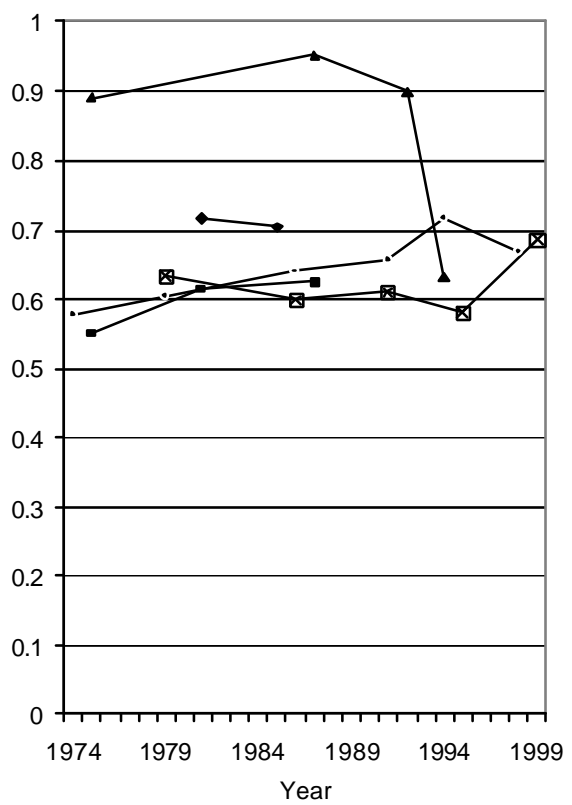

Panel B: 1910-1919

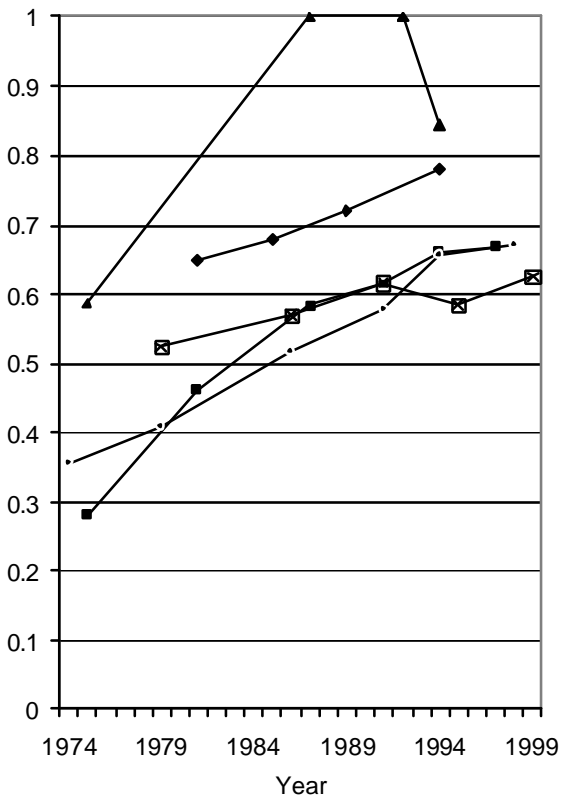

Panel C: 1920-1929

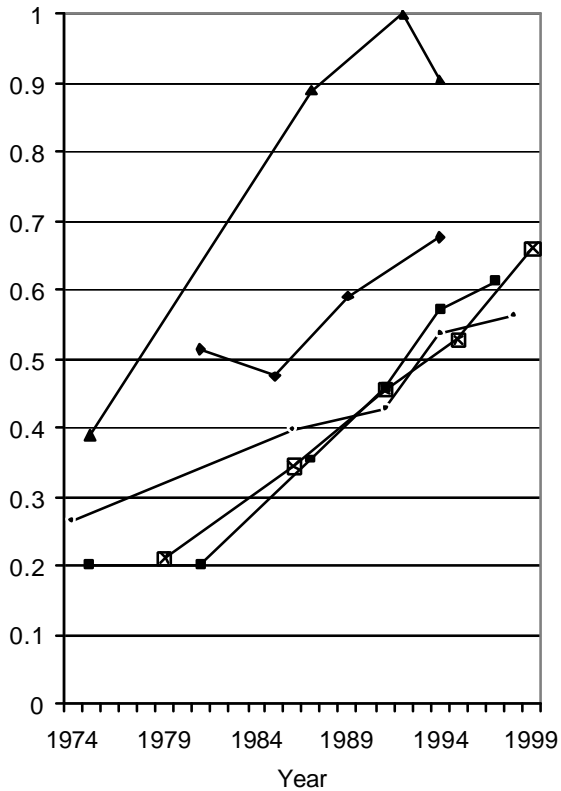

Figure $4 \mathrm{a}$

Percent who receive social retirement benefits

Panel A: 1900-1909

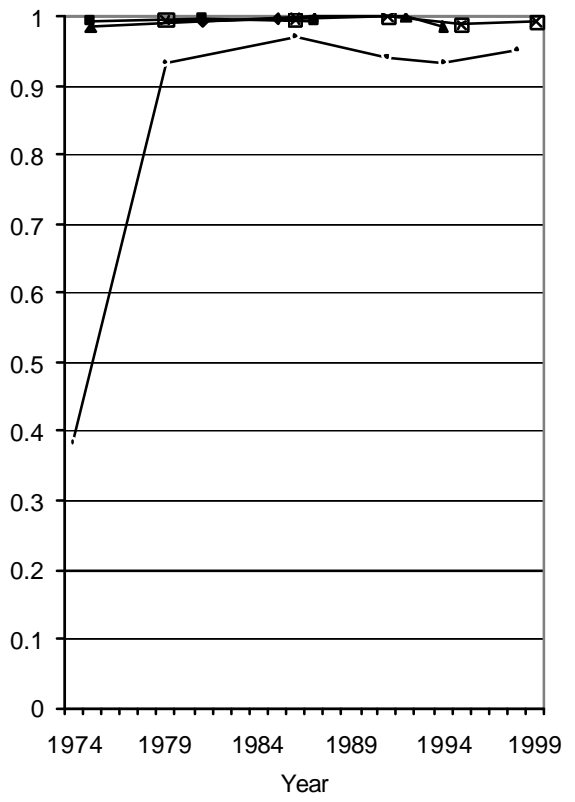

Panel B: 1910-1919

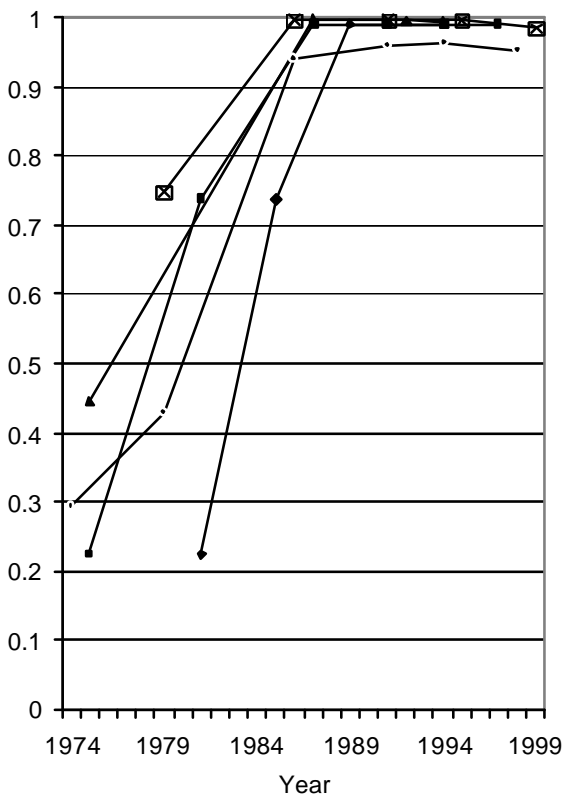

Panel C: 1920-1929

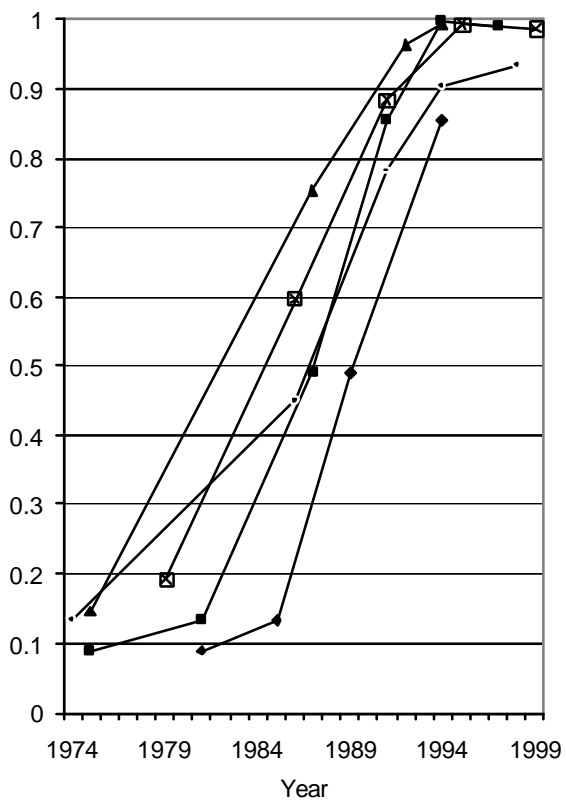


Figure 5

Social transfer benefits as a percentage of personal disposable income

Panel A: 1900-1909

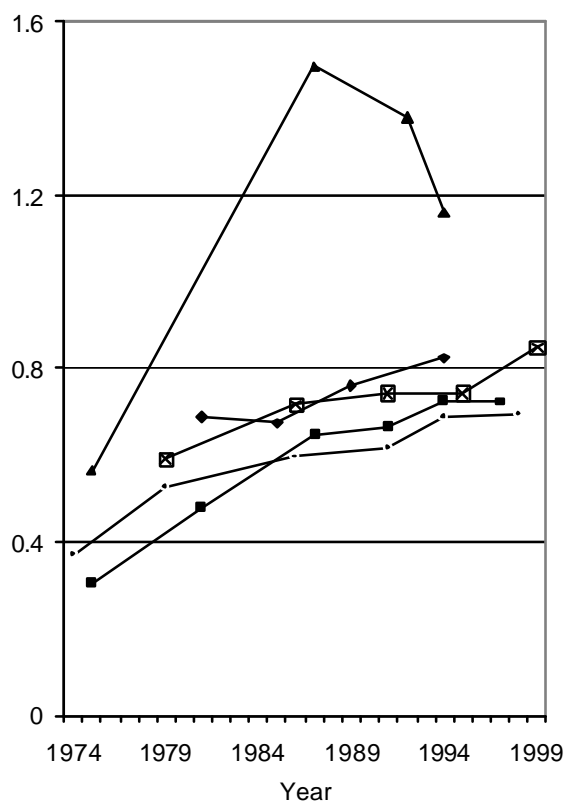

Panel B: 1910-1919

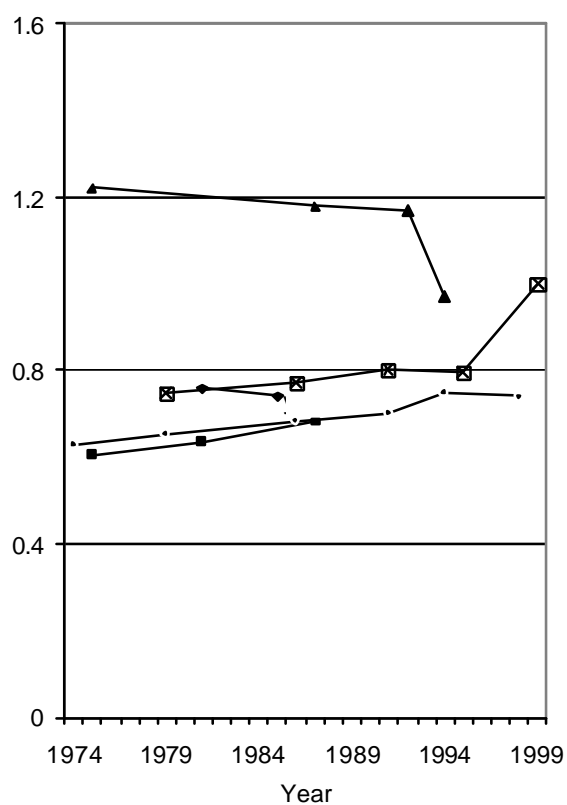

Panel C: $1920-1929$

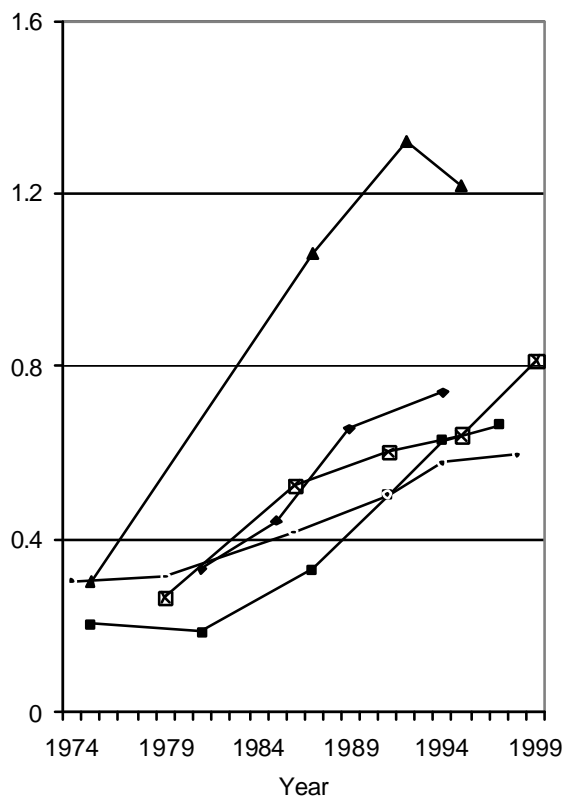

Figure 5a

Percent who receive social transfer benefits

Panel A: 1900-1909

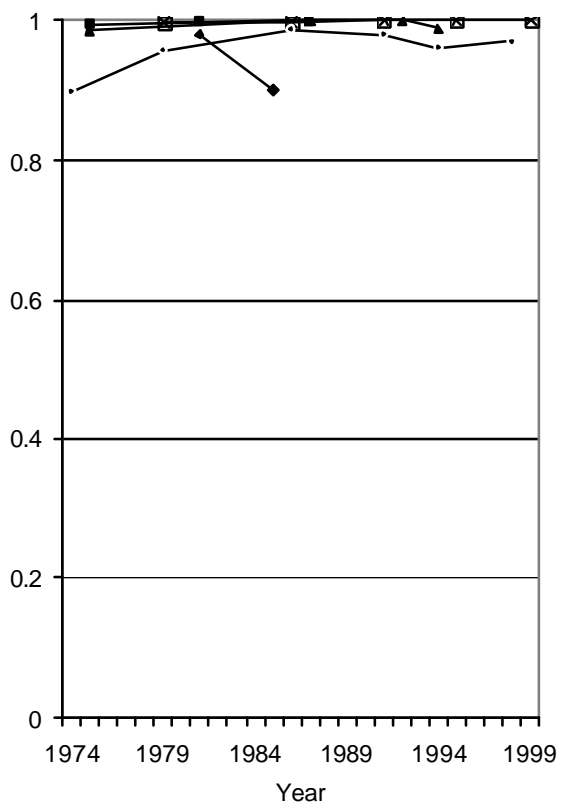

Panel B: 1910-1919

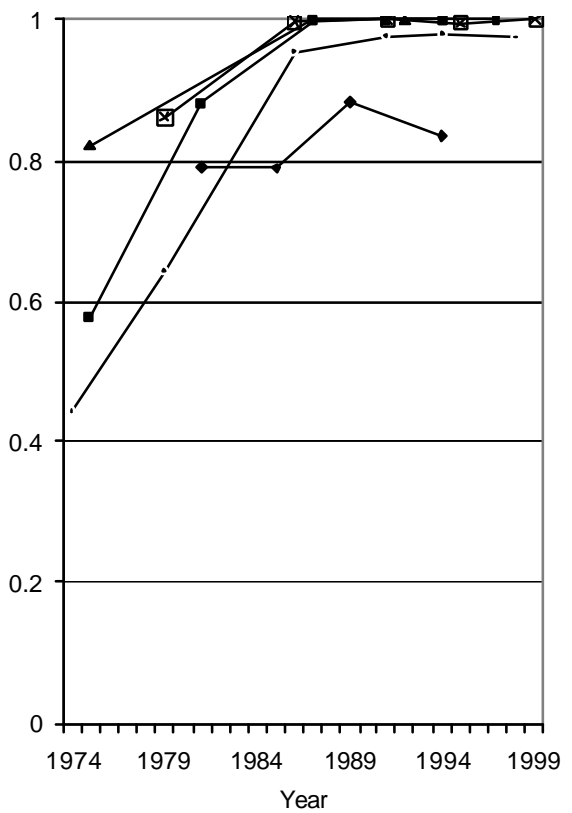

Panel C: $1920-1929$

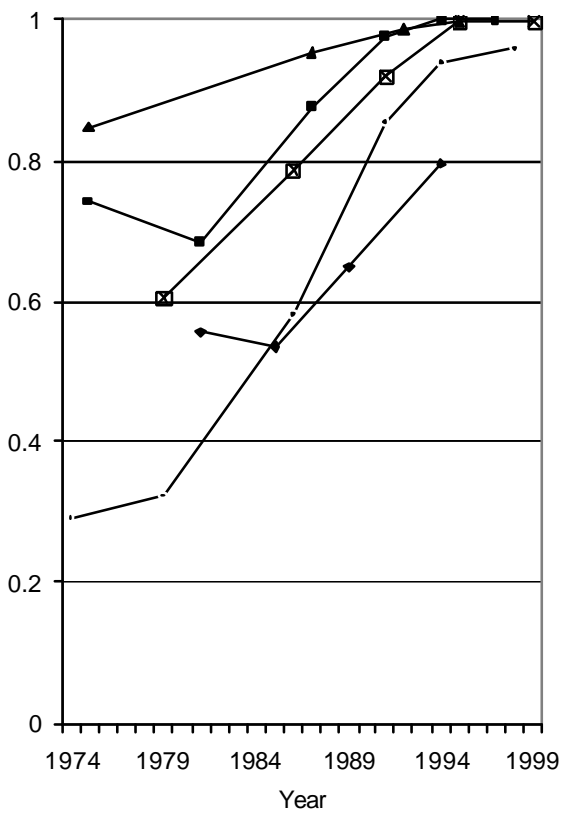


Figure 6

Percentage of women in poverty: $50 \%$ of the median disposable personal income

Panel A: 1900-1909

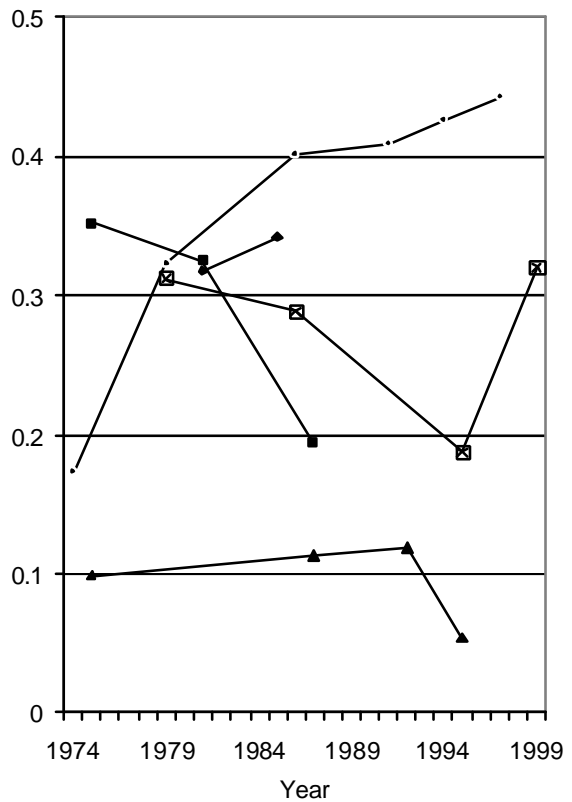

Panel B: 1910-1919

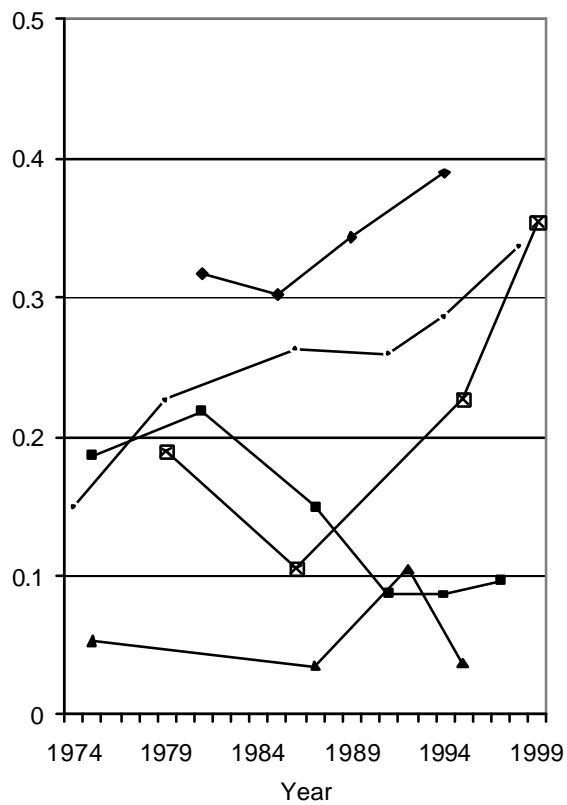

Panel C: $1920-1929$

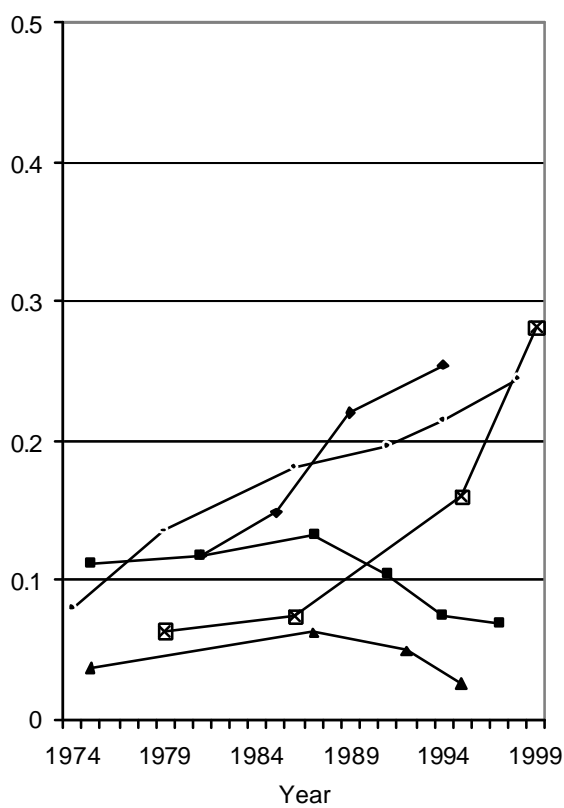

Figure 7

Percentage of men in poverty: $50 \%$ of the median disposable personal income

Panel A: 1900-1909

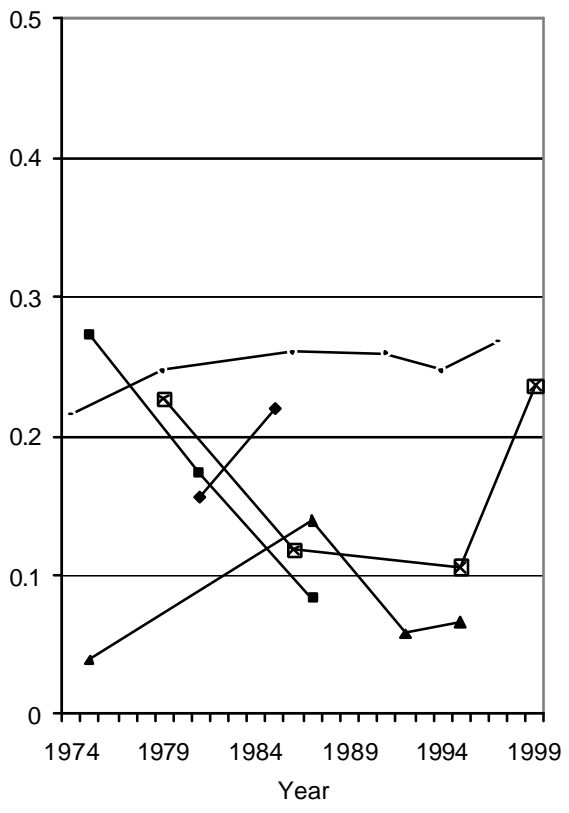

Panel B: 1910-1919

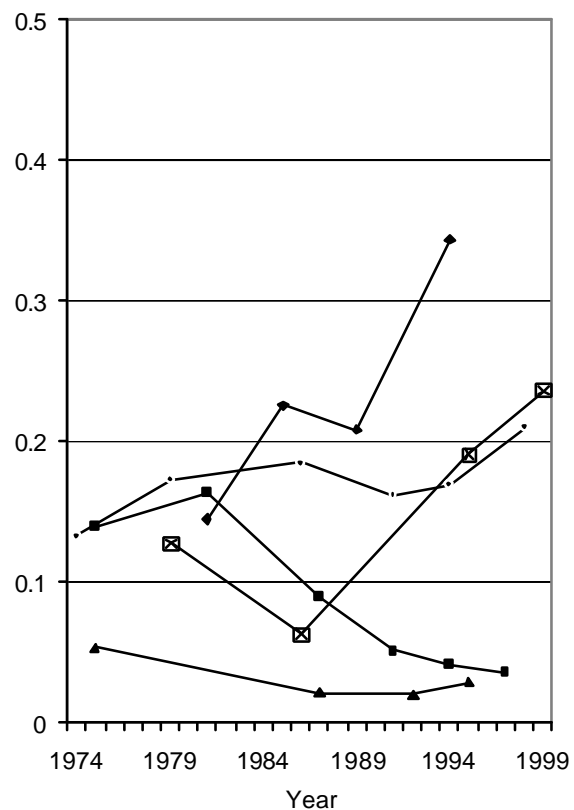

Panel C: 1920-1929

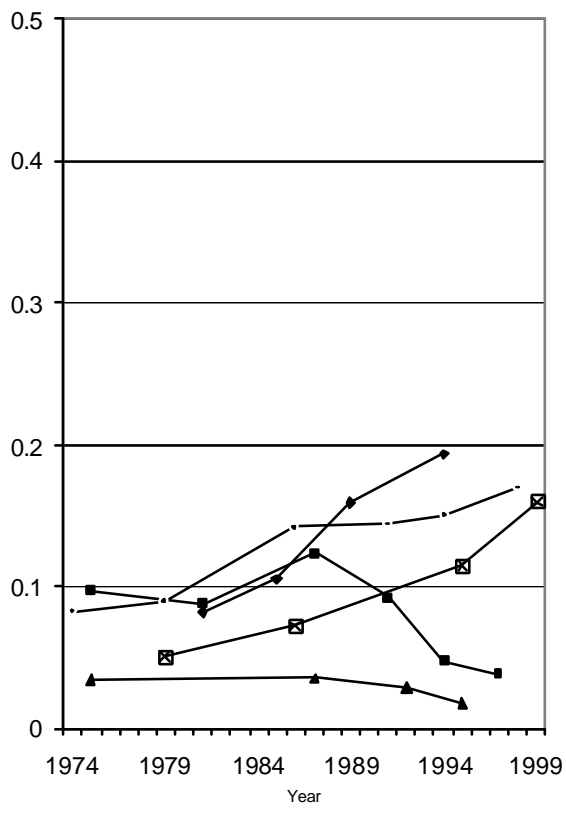

$\rightarrow$ Australia $\rightarrow$ Canada $\rightarrow$ Sweden $\rightarrow$ United Kingdom $\quad--$ United States 
Figure 8

Women in Poverty: $40 \%$ of Median Disposable In come

Panel A: 1900-1909

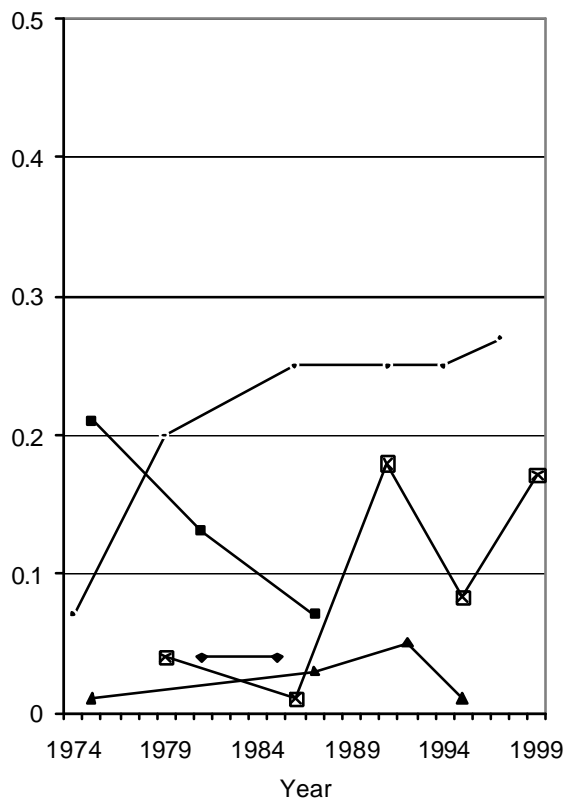

Panel B: 1910-1919

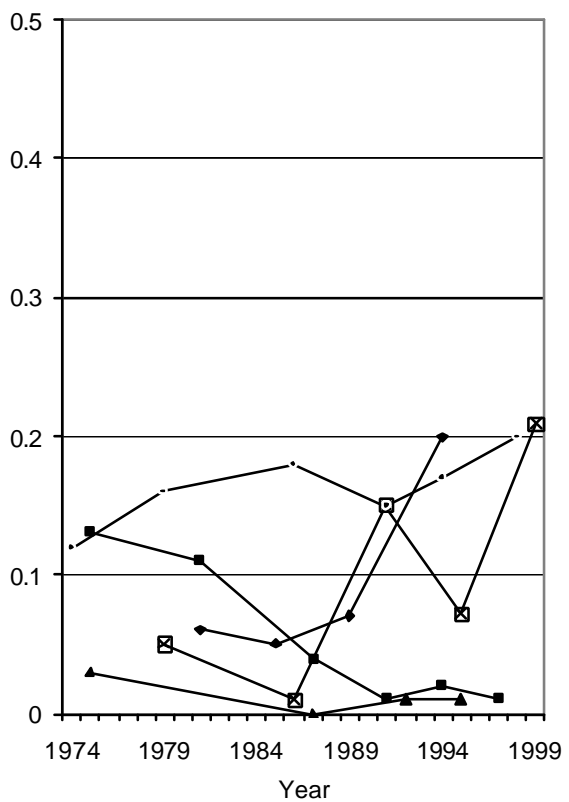

Panel C: 1920-1929

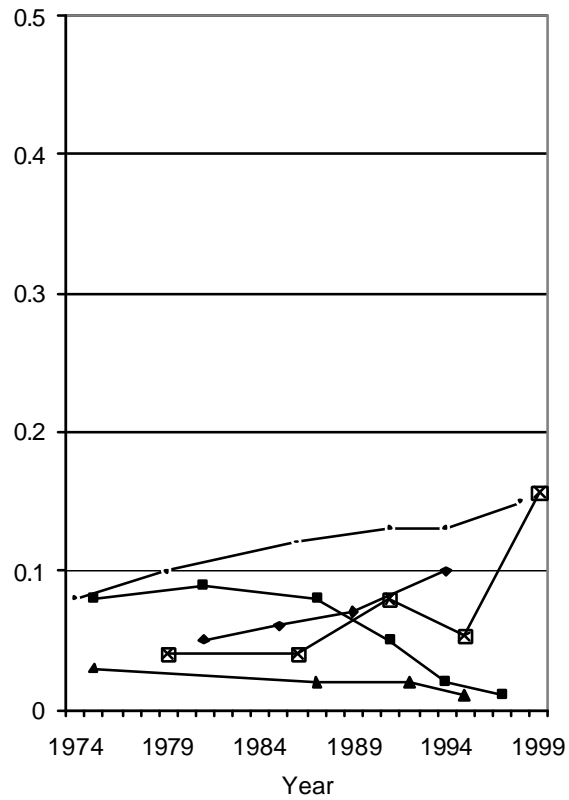

Figure 9

Men in Poverty: 40\% of Median Disposable Income

Panel A: 1900-1909

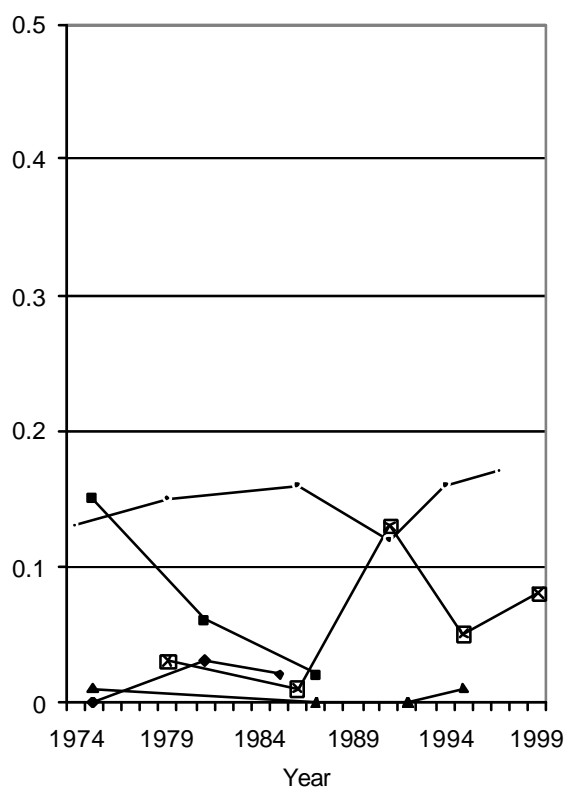

Panel B: 1910-1919

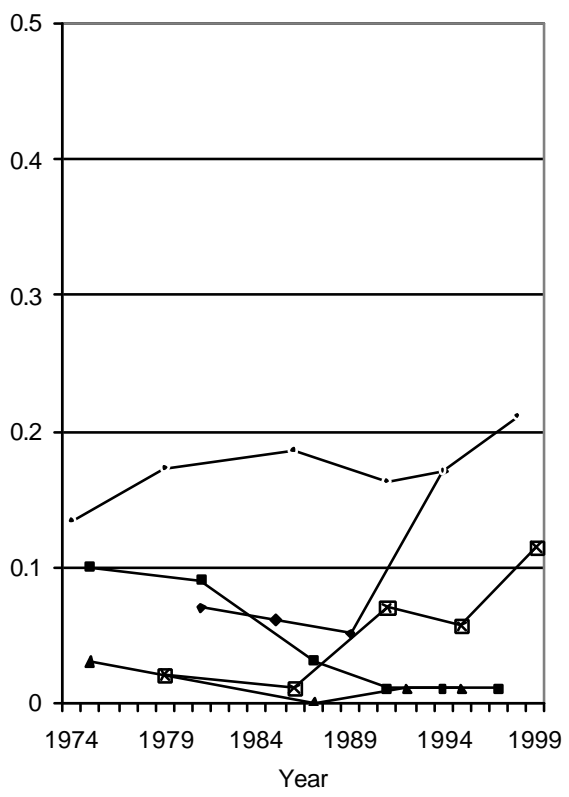

Panel C: 1920-1929

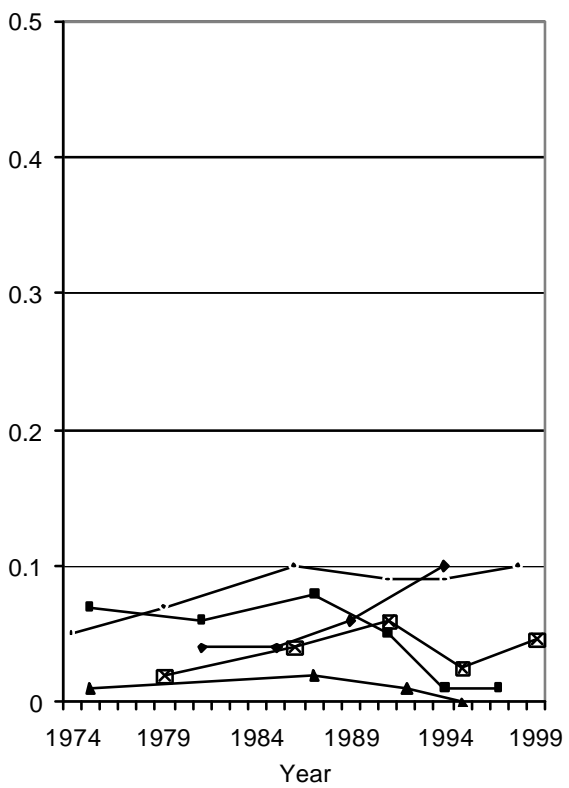


Figure 10

Poverty rates of homeowners and renters by birth cohort

Homeowners

Panel A: 1900-1909

Panel B: 1910-1919

Panel C: 1920-1929

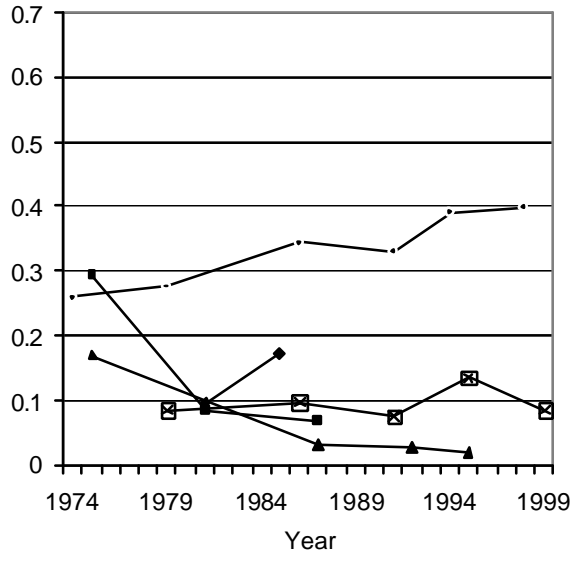

Panel A: 1900-1909

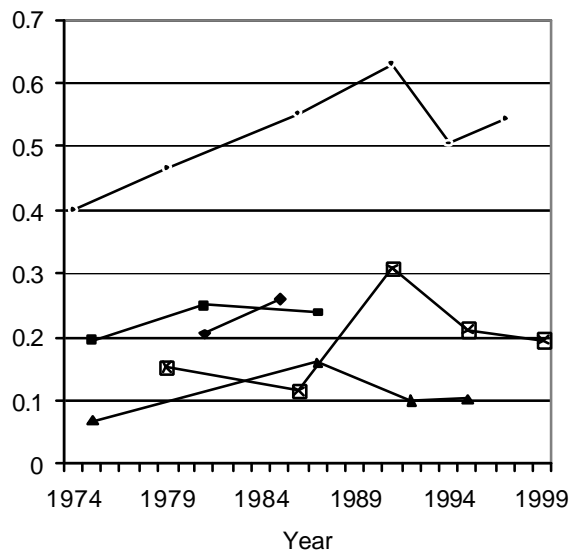

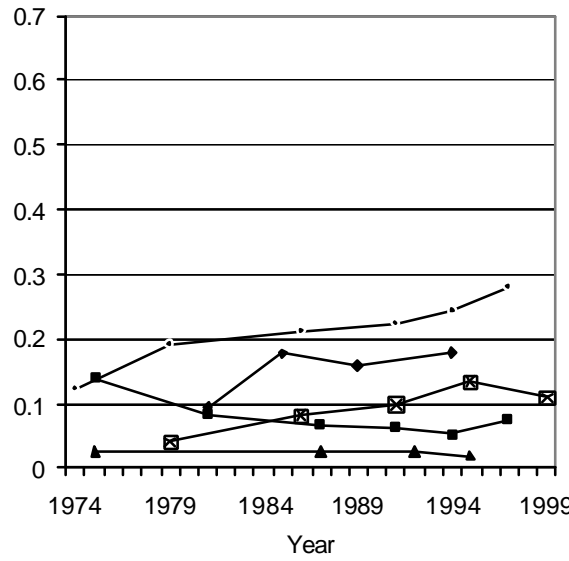

Renters

Panel B: 1910-1919

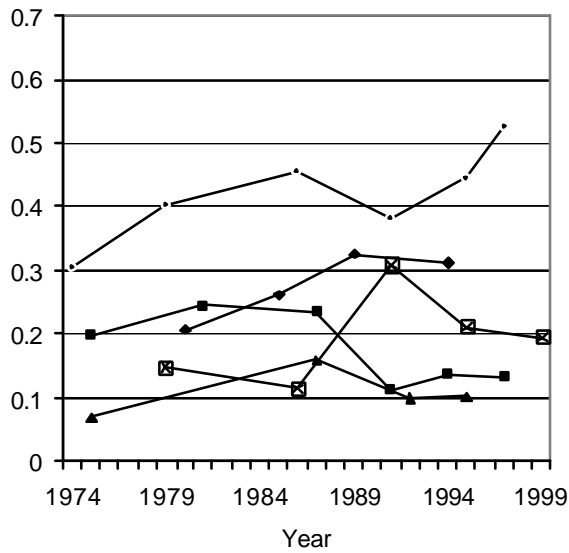

Panel C: 1920-1929

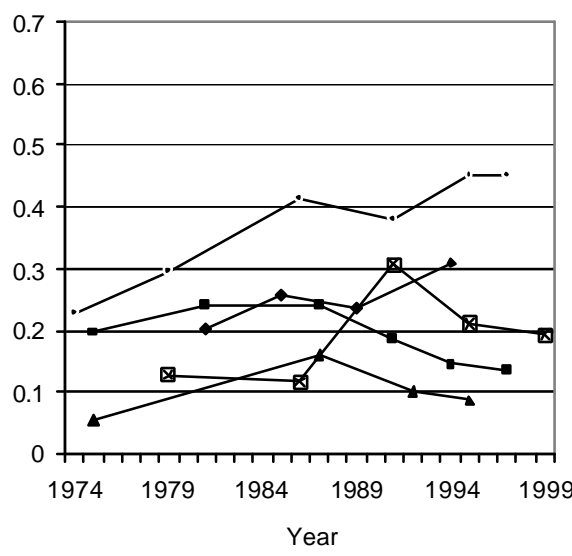

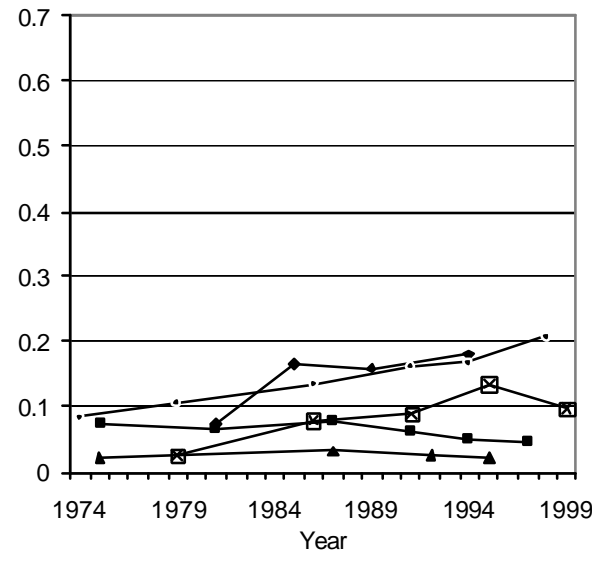


Figure 11

Relative median disposable personal income by birth cohort

Homeowners

Panel A: 1900-1909

Panel B: 1910-1919

Panel C: 1920-1929

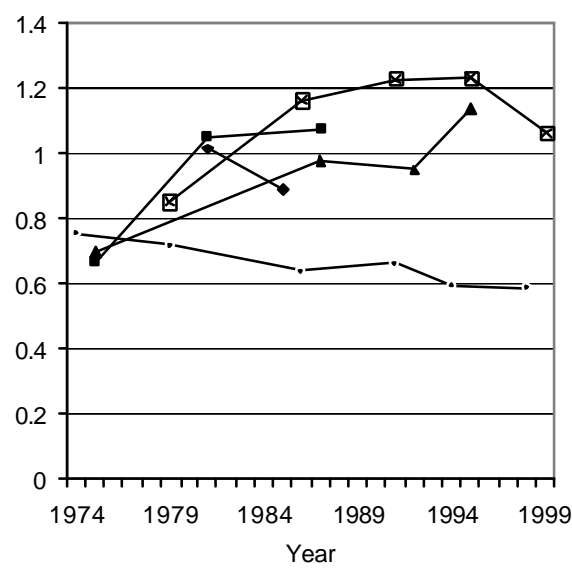

Panel A: 1900-1909

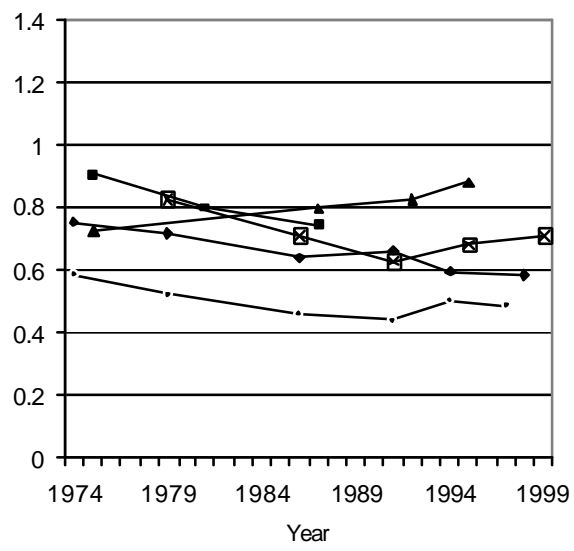

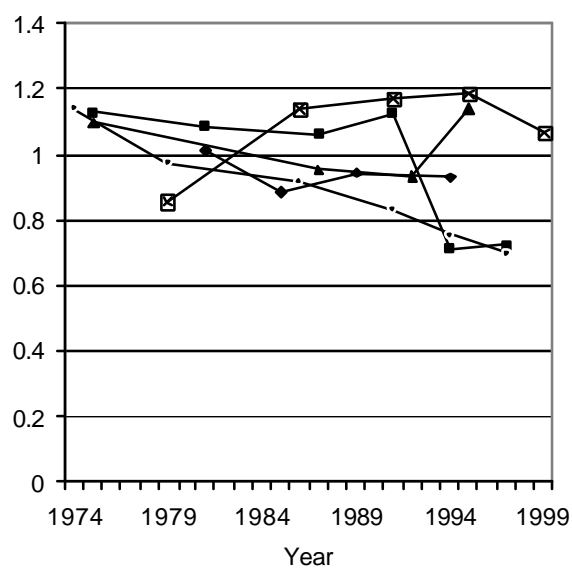

Renters

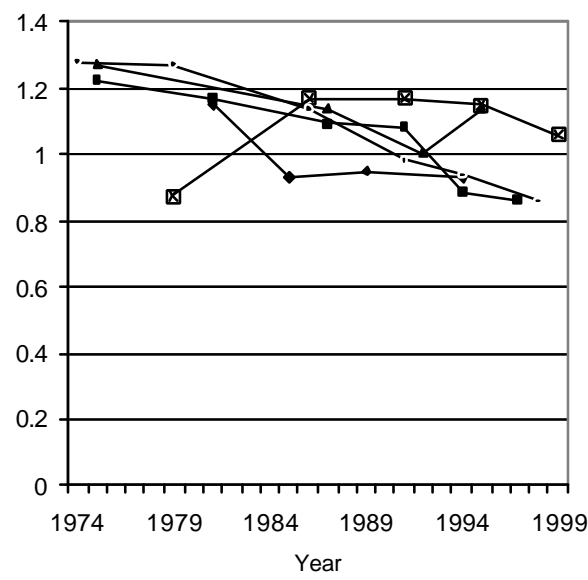

Panel C: 1920-1929
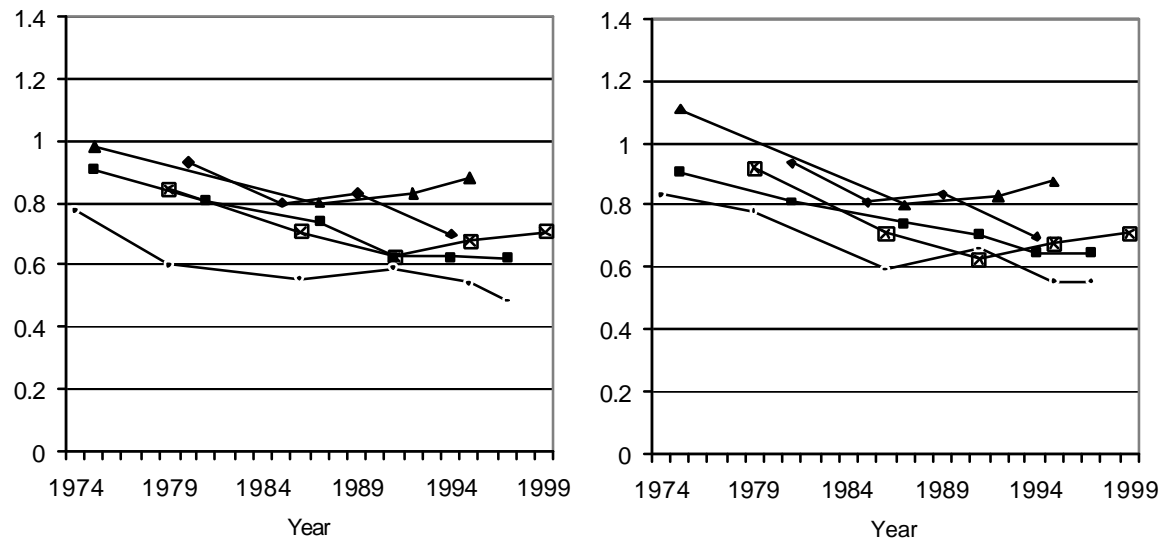



\section{RECENT WORKING PAPERS FROM THE \\ CENTER FOR RETIREMENT RESEARCH AT BOSTON COLLEGE}

Why Don't Americans Save

Barry Bosworth, November 2004

How Do Pensions Affect Expected and Actual Retirement Ages?

Alicia H. Munnell, Robert K. Triest, and Natalia A. Jivan

Sliding Into Poverty? Cross-National Patterns of Income Source Change and Income Decay in Old Age

James M. Williamson and Timothy M. Smeeding

The Well-Being Of Retirees: Evidence Using Subjective Data

Keith A. Bender, November 2004

The Impact of Aging on Financial Markets and the Economy: A Survey

Barry P. Bosworth, Ralph C. Bryant and Gary Burtless, October 2004

Social Security Personal-Account Participation with Government Matching

Gary V. Engelhardt and Anil Kumar, October 2004

Providing Guarantees in Social Security

Karen E. Smith, C. Eugene Steuerle, and Pablo Montagnes, August 2004

Deferring Income in Employer-Sponsored Retirement Plans: The Dynamics of Participant Contributions

Karen E. Smith, Richard W. Johnson, and Leslie A. Muller, August 2004

Reform Model Two of the President's Commission to Strengthen Social Security: Distributional Outcomes Under Different Economic and Behavioral Assumptions Melissa M. Favreault, Joshua H. Goldwyn, Karen E. Smith, Lawrence H. Thompson, Cori E. Uccello, and Sheila R. Zedlewski, August 2004

An Analysis of How Individuals React to Market Returns in One 401(k) Plan Julie Agnew, April 2004

The Effects of Health Insurance and Self-Insurance on Retirement Behavior Eric French and John Bailey Jones, April 2004

Valuing Assets in Retirement Saving Accounts

James M. Poterba, April 2004

All working papers are available on the Center for Retirement Research website (http://www.bc.edu/crr) and can be requested by e-mail (crr@ bc.edu) or phone (617-552-1762). 